Heartwarming Effect of BAT

The Heartwarming Effect of Brown Adipose Tissue

Kelsey M. Pinckard ${ }^{1,2}$ and Kristin I. Stanford ${ }^{1,2,3}$

${ }^{1}$ Department of Physiology and Cell Biology, The Ohio State University Wexner Medical Center, Columbus, $\mathrm{OH}$

${ }^{2}$ Center for Diabetes and Metabolism Research Center, Dorothy M. Davis Heart and Lung Research Institute, The Ohio State University Wexner Medical Center, Columbus, $\mathrm{OH}$

${ }^{3}$ Department of Internal Medicine, The Ohio State University Wexner Medical Center, Columbus, $\mathrm{OH}$

To whom correspondence should be addressed:

Kristin I. Stanford

460 W. $12^{\text {th }}$ Ave.

Columbus, $\mathrm{OH} 43210$

Phone: 614-247-8287

kristin.stanford@osumc.edu

Total text pages: 19

Number of figures: 1

Number of tables: 1

Abstract wordcount: 173

Introduction wordcount: 158

Discussion wordcount: 840

Number of citations: 138

Financial disclosure: No author has an actual or perceived conflict of interest with the contents of this article 
Heartwarming Effect of BAT

Non-standard abbreviations:

AKT: protein kinase B

ApoE: apolipoprotein E

ATGL: adipose triglyceride lipase

A2AR: adenosine $2 \mathrm{~A}$ receptor

BAT: brown adipose tissue

BMI: body mass index

$B_{1-3}$-AR: Beta 1-3 adrenergic receptor

cAMP: cyclic adenosine monophosphate

$C A D$ : coronary artery disease

CBD: cobalamin-binding domain

CETP: cholesterol ester transfer protein

CVD: cardiovascular disease

DOCA: deoxycorticosterone acetate

ERK: extracellular-signal-regulated kinase

FA: fatty acid

FGF21: fibroblast growth factor 21

[18F]FDG: fluorodeoxyglucose

HDL: high density lipoprotein

HSL: hormone sensitive lipase

IL6: interleukin 6

iBAT: intrascapular BAT

LDLR: low-density lipoprotein receptor

MI: myocardial infarction

PET: positron emission tomography

PKA: protein kinase $A$ 


\section{Heartwarming Effect of BAT}

PRDM16: PR domain containing 16

PUFA: poly unsaturated fatty acids

SNS: sympathetic nervous system

TAG: triacylglycerol

TGs: triglycerides

TNT: tissue nano-transfection

T2D: type II diabetes

UCP1: uncoupling protein 1

WAT: white adipose tissue

WT: wild-type

12-LOX: 12-lipoxygenase 
Molecular Pharmacology Fast Forward. Published on December 21, 2021 as DOI: 10.1124/molpharm.121.000328

This article has not been copyedited and formatted. The final version may differ from this version.

Heartwarming Effect of BAT

\section{Abstract}

Brown adipose tissue (BAT) is a metabolically active tissue that improves glucose metabolism and protects against the development of type 2 diabetes and obesity. However, the role of BAT to improve cardiovascular health has only recently been investigated. In this review, we discuss multiple mechanisms through which both the thermogenic and endocrine functions of BAT mediate cardiac health. $\beta$-adrenergic stimulation activates the thermogenic function of BAT, resulting in reduced circulating lipids and glucose, and enhanced clearance of hepatic cholesterol-enriched remnants leading to reduced atherosclerotic region size. Additionally, the thermogenic role of BAT has been implicated in activation of the AKT-ERK1/2 pathway after myocardial infarction (MI), contributing to reduced injury size. The endocrine function of BAT has also been implicated to improve both systemic metabolic health and cardiac health. Specifically, the batokines FGF21 and 12,13-diHOME improve cardiovascular health via reduced hypertension, hypertrophy and MI injury size (FGF21) or by directly improving cardiac function via improved calcium cycling (12,13-diHOME). Finally, we discuss relevant pharmacological treatment methods currently aiming to activate BAT, typically through sympathetic activation.

\section{Significance}

This mini-review discusses the role of BAT to improve cardiac health via thermogenic and endocrine effects in both rodents and humans, and highlights the need for therapeutic methods which activate or mimic BAT activity. 
Molecular Pharmacology Fast Forward. Published on December 21, 2021 as DOI: 10.1124/molpharm.121.000328

This article has not been copyedited and formatted. The final version may differ from this version.

Heartwarming Effect of BAT

\section{Introduction}

Cardiovascular disease (CVD) is the leading cause of death in the U.S. and worldwide (Prevention. 2018; Organization 2018). The presence of obesity and type 2 diabetes (T2D) significantly increase the risk for development of CVD (Van Gaal, Mertens, and De Block 2006; Carbone et al. 2019). Obesity, T2D and CVD are increasing at rapid rates across the United States and worldwide (Hales CM 2017; Moore, Chaudhary, and Akinyemiju 2017) thus determining potential tools to combat these diseases is of utmost importance. An important tissue to combat both obesity and T2D is brown adipose tissue (BAT), however a role for BAT to provide a protective role in CVD has only recently been investigated. Recent studies have now identified a direct role for BAT to mediate cardiac function in mice and reduce CVD risk in rodents and humans (Figure 1) (Berbee et al. 2015; Ruan et al. 2018; Thoonen et al. 2015; Pinckard et al. 2021; Becher et al. 2021).

\section{Brown Adipose Tissue (BAT)}

Adipose tissue is a specialized connective tissue consisting of several cell types including preadipocytes, adipose-derived stem cells and immune cells, and lipid-rich adipocytes (Esteve Rafols 2014). Adipose tissue functions in both lipid storage and lipolysis and is a vital tissue for maintaining energy intake and expenditure. There are three main types of adipose tissue found in rodents and humans, white adipose tissue (WAT), brown adipose tissue (BAT), and beige, or brite (or brown-in-white) adipose tissue. WAT and BAT differ markedly in morphology and function. White adipocytes consist of a single large lipid droplet and possess only a few mitochondria, while brown adipocytes contain multiple lipid droplets per cell and are packed with mitochondria (Betz and Enerback 2015). BAT is densely innervated by the sympathetic nervous system (SNS) and is highly vascularized. Beige adipocytes are found in WAT depots, but have morphological and functional similarities to BAT with high levels of mitochondria, increased expression of uncoupling protein 1 (UCP1), and multi-locular lipid droplets (Wu et al. 2012) 
Molecular Pharmacology Fast Forward. Published on December 21, 2021 as DOI: 10.1124/molpharm.121.000328

This article has not been copyedited and formatted. The final version may differ from this version.

Heartwarming Effect of BAT

\subsection{BAT in humans versus rodents}

While the importance of BAT in rodents for thermogenesis and whole-body metabolism is well-established, it was historically believed that functional BAT only existed in human infants, rapidly decreasing through childhood and disappearing in adulthood. However, in the late 2000's, several studies identified functional BAT in adult humans through the use of retrospective analysis of nuclear medicine images of radiolabeled fluorodexyglucose $\left(\left[{ }^{18} \mathrm{~F}\right] \mathrm{FDG}\right)$ positron emission tomography (PET) and computer tomography (CT) (Cypess et al. 2009; Nedergaard, Bengtsson, and Cannon 2007; van Marken Lichtenbelt et al. 2009; Virtanen et al. 2009). This "rediscovery" of BAT in humans invigorated interest in BAT as a therapeutic target, and has led to several important studies which determined BAT as a mediator of metabolic health in humans (Bakker et al. 2014; van der Lans et al. 2013; Lee et al. 2014).

BAT differs markedly among humans and rodents. Rodents possess five BAT depots, with the largest being a large well-delineated interscapular BAT (iBAT) depot (Lehnig et al. 2019). Conversely, human BAT depots are not well defined and are located in the supraclavicular and neck regions, as well as the paravertebral, mediastinal, para-aortic, and suprarenal areas (Nedergaard, Bengtsson, and Cannon 2007). Some human BAT depots have been described as more similar in appearance to rodent beige adipocytes rather than the traditional BAT depots; however, the gene expression profile of human BAT is similar to classical rodent BAT (Cannon et al. 2020; Cypess et al. 2009; Cypess et al. 2013).

In addition to differences in depot location, there is also a large difference in the amount of BAT found in humans versus rodents. In humans, BAT accounts for $0.1 \%$ of an individual's body weight, which is 5-10 times lower than that of the mouse (van Marken Lichtenbelt and Schrauwen 2011; Virtanen et al. 2009). BAT is thus responsible for less of the resting metabolic rate in humans than in rodents. Despite this, there is still a significant correlation between coldinduced BAT activity, non-shivering thermogenesis, and insulin sensitivity in humans (Bakker et al. 2014; van der Lans et al. 2013; Lee et al. 2014). These data suggest that although the BAT 
Molecular Pharmacology Fast Forward. Published on December 21, 2021 as DOI: 10.1124/molpharm.121.000328

This article has not been copyedited and formatted. The final version may differ from this version.

\section{Heartwarming Effect of BAT}

depots may be different in quantity and location between rodents and humans, both have a profound effect on systemic metabolism.

BAT activation also differs between mice and humans. While $\beta_{3^{-}}$adrenergic receptors $\left(\beta_{3^{-}}\right.$ ARs) are the predominant regulators of BAT thermogenesis in rodents (Zhao et al. 1994), $\beta_{1}$ and $\beta_{2}$-ARs are the primary regulators of BAT metabolism and thermogenesis in humans (RiisVestergaard et al. 2020; Blondin et al. 2020). However, treatment with the $\beta_{3}-A R$ agonist mirabegron is somewhat effective at eliciting a response in human BAT. One study in humans found that maximal oral treatment with mirabegron $(200 \mathrm{mg})$ increased BAT oxidative metabolism, blood flow, and glucose uptake in vivo, although at a much lower rate than cold exposure (Blondin et al. 2020). In contrast, treatment with a therapeutic dose of mirabegron (50mg) did not affect BAT (Blondin et al. 2020). The authors suggest that at high enough doses, mirabegron treatment induces non-specific adrenergic responses in human tissues, as indicated by adrenergic response to $200 \mathrm{mg}$ mirabegron treatment in the heart (an organ primarily driven by $\beta_{1}$-ARs) (Blondin et al. 2020). In addition, an in vitro study found that mirabegron treatment $(10 \mu \mathrm{M})$ stimulated lipolysis and thermogenesis in human brown/beige adipocytes in vitro, although treatment with $\beta_{1}$ and $\beta_{2}-A R$ agonist treatments had stronger impacts on brown adipocyte respiration (Cero et al. 2021). Together, these data suggest $\beta_{1}$ - and $\beta_{2}$ are the main ARs responsible for BAT activation in humans, but that $\beta_{3}$-AR agonist mirabegron treatment may still stimulate BAT in humans at high enough doses.

There are several factors that contribute to the functionality of BAT in humans. Human studies show that BAT is negatively correlated with BMI, fasting glucose, and age (Cypess et al. 2009; Saito et al. 2009). Young lean women have higher BAT mass (more BAT positive PET-CT scans) and activity (higher $\left[{ }^{18} \mathrm{~F}\right] \mathrm{FDG}$ uptake) compared to men and older individuals in human studies (Cypess et al. 2009). BAT mass and activity are therefore affected by sex, age, and body composition, highlighting the need to find therapeutic methods to maintain BAT mass and activity in such circumstances. 
Molecular Pharmacology Fast Forward. Published on December 21, 2021 as DOI: 10.1124/molpharm.121.000328

This article has not been copyedited and formatted. The final version may differ from this version.

Heartwarming Effect of BAT

\subsection{BAT thermogenic activity}

BAT is highly thermogenic tissue which dissipates chemical energy as heat by uncoupling oxidative phosphorylation in the mitochondria via UCP1 (Cannon and Nedergaard 2004). In both rodents and humans, BAT is densely innervated by the sympathetic nervous system (SNS), which controls BAT activation of thermogenesis via norepinephrine. Norepinephrine binds to $\beta$-adrenergic cell surface receptors $\left(\beta_{1-3}\right)$; all three subtypes of which are expressed in brown adipocytes (Rohlfs et al. 1995) although their relative abundance varies by location and species (as discussed above) (Lafontan and Berlan 1993). The signaling pathway invoked by $\beta$ stimulation is mediated by cyclic adenosine monophosphate (cAMP) and protein kinase A (PKA) (Thoonen, Hindle, and Scherrer-Crosbie 2016; Pagnon et al. 2012). Activation of hormonesensitive lipase (HSL) and adipose triglyceride lipase (ATGL) leads to lipolysis of intracellular triglycerides (TGs) resulting in the release of fatty acids. The fatty acids are metabolized in the mitochondria by $\beta$-oxidation, and additionally activate UCP1.

UCP1 is a mitochondrial inner membrane protein and proton channel, which is stabilized by cardiolipin. This proton pump allows thermogenic capacity to be controlled by the central nervous system via norepinephrine. Fatty acids (FA) derived from TGs are the main energy source for BAT thermogenesis, but glucose is also used by BAT for ATP generation (via glycolysis) (Carpentier et al. 2018).

Thus, increased BAT mass and activity decreases circulating FA and glucose, protecting against the development of T2D and obesity (Cypess et al. 2013; Stanford et al. 2013; Cannon and Nedergaard 2004). Because of its role in thermogenesis and energy expenditure, BAT is an attractive topic of investigation for the regulation of both systemic metabolism and cardiovascular diseases.

\subsection{BAT endocrine activity}

In rodents, BAT is also known to have a crucial secretory role which contributes to the systemic consequences of BAT activity. BAT releases 'batokines', including signaling lipids, 
Molecular Pharmacology Fast Forward. Published on December 21, 2021 as DOI: 10.1124/molpharm.121.000328

This article has not been copyedited and formatted. The final version may differ from this version.

\section{Heartwarming Effect of BAT}

proteins, metabolites or microRNAs (Villarroya et al. 2019; Lee, Lee, and Oh 2019). These batokines can act in an autocrine, paracrine, or endocrine manner to mediate systemic physiology. Most paracrine factors released from BAT (adenosine, nitric oxide, neuregulin-4, S100b protein, bone morphogenetic protein-8b, C-X-C motif chemokine ligand-14) function to promote hypertrophy and hyperplasia of BAT. This can include increased BAT vascularization, innervation, and blood flow, all processes associated with BAT recruitment and thermogenic activity (Villarroya et al. 2019; Villarroya, Cereijo, et al. 2017). More important for systemic metabolism, BAT can release signaling molecules that act on other tissues and organs. These signaling molecules include peptides, lipids, or exosomal microRNAs (Villarroya et al. 2019; Lee, Lee, and Oh 2019; Kiefer 2017).

A multitude of studies have demonstrated the efficacy of increased BAT mass or activity through transplantation, activation via cold exposure, or direct $\beta$-adrenergic stimulation to improve human and rodent metabolic health is likely related to the thermogenic or endocrine functions of BAT (Cypess et al. 2013; Stanford et al. 2013; Cannon and Nedergaard 2004). The role of BAT to improve cardiac function, however, has only recently become a topic of investigation.

\section{BAT and Cardiovascular Disease}

Studies in rodents show that increasing BAT mass or activity has the capacity to reduce many cardiovascular risk factors, including obesity (White, Dewal, and Stanford 2019; Wang, Zhang, et al. 2015; Yoneshiro et al. 2013), insulin resistance (Stanford et al. 2013), and T2D (Cypess and Kahn 2010). However, BAT mass and activity are known to decrease with increasing BMI, fasting glucose, and age in humans (Cypess et al. 2009)

Studies in humans and rodents have also identified reduced BAT mass or activity in instances of cardiovascular disease, independent of the presence of metabolic disease (Takx et al. 2016; Thoonen et al. 2015). Here, we will discuss the impact of both the thermogenic and 
Molecular Pharmacology Fast Forward. Published on December 21, 2021 as DOI: 10.1124/molpharm.121.000328

This article has not been copyedited and formatted. The final version may differ from this version.

Heartwarming Effect of BAT

endocrine functions of BAT on various cardiovascular diseases including atherosclerosis, hypertension, and myocardial infarction, as well as on general cardiac function (Figure 1).

\subsection{Atherosclerosis}

Atherosclerosis or coronary artery disease (CAD) is the most common form of CVD. Obesity and hyperlipidemia are two of the main causes of atherosclerosis, thus BAT may be an attractive therapy for prevention of CAD development (Rocha and Libby 2009; Berbee et al. 2015; Becher et al. 2021). In a study of 443 human patients (44\% male, $56 \%$ female, mean age 55 years, mean BMI 26), BAT activity (determined by ${ }^{18} \mathrm{~F}-\mathrm{FDG}$ uptake in supraclavicular BAT) was negatively correlated with arterial inflammation, even after correcting for age and BMI (Takx et al. 2016). A longitudinal study in healthy human adults found that cold-induced BAT activity was negatively correlated with atherosclerosis markers and positively associated with healthy vessel function 5 years after baseline BAT measurements were recorded (Raiko et al. 2020). Together these studies indicate that BAT may be athero-protective in healthy adults. However, whether the correlation between BAT and reduced atherosclerotic risk is direct or indirect in response to improved metabolic health in these individuals (and therefore reduced risk for CVD) has not been determined.

Mouse studies also suggest that BAT thermogenic activity is correlated with atherosclerosis; both C57BL6 WT and $\mathrm{ApoE}^{-/-}$mice housed at thermoneutrality have accelerated onset of atherosclerosis (Tian et al. 2016; Giles et al. 2016). It is not clear if lack of BAT activity at thermoneutrality is causative or correlated to the accelerated atherosclerosis development; studies measuring BAT activity in thermoneutral versus ambient temperature housed mice utilizing BAT transplant or inhibition methods are necessary to investigate this mechanistic link.

Other rodent studies have investigated the mechanistic roles of BAT to directly affect CAD. Berbee et al used E3L.CETP mice, a well-established model for human-like atherosclerosis that expresses functional apoE and LDLR, to study the role of BAT activity in a model of CAD (Berbee et al. 2015). The authors found that BAT activation by $\beta_{3}-A R$ stimulation enhanced the 
Molecular Pharmacology Fast Forward. Published on December 21, 2021 as DOI: 10.1124/molpharm.121.000328

This article has not been copyedited and formatted. The final version may differ from this version.

\section{Heartwarming Effect of BAT}

selective uptake of fatty acids from TG-rich lipoproteins into BAT, accelerating the hepatic clearance of the cholesterol-enriched remnants (Berbee et al. 2015). As a result, BAT activation reduced atherosclerotic lesion size and disease severity in E3L.CETP mice; however this effect was not seen in $a p o E^{/-}$or $L D L R^{-/}$mice. These exciting data indicate that BAT mediates local lipolysis of TG-rich lipoproteins and stimulates hepatic clearance through the apoE-LDLR pathway (Berbee et al. 2015). Together these studies show a correlation between BAT activity and atherosclerosis in mice and humans (Tian et al. 2016; Giles et al. 2016; Takx et al. 2016), and also indicate a mechanistic role for BAT to directly mediate atherosclerosis development via hepatic clearance of cholesterol-enriched remnants (Berbee et al. 2015); indicating the potential therapeutic role of BAT as a treatment for atherosclerosis.

\subsection{Hypertension}

Hypertension, or high blood pressure is one of the most common risk factors for CVD, causing pathologic cardiac remodeling eventually leading to heart failure (Messerli, Rimoldi, and Bangalore 2017). A review of ${ }^{18} \mathrm{~F}-\mathrm{FDG}$ PET/CT reports conducted in 53,475 human patients found lower rates of cardiometabolic diseases, including hypertension, among patients with active BAT (Becher et al. 2021). Interestingly, the correlation between increased BAT activity and reduced cardiometabolic diseases was more pronounced in obese individuals, indicating active BAT can offset the detrimental effects of obesity in humans (Becher et al. 2021). It is surprising that increased BAT activity is correlated with reduced rates of hypertension, given that hypertension is associated with increased sympathetic activity, which should be associated with more active BAT. This suggests divergent pathways of SNS activation to mediate hypertension versus BAT activation.

To understand the relationship between BAT activity and hypertension, Ruan, et al utilized three mouse models of hypertension: a WT deoxycorticosterone acetate (DOCA)-salt sensitive mouse, an adenosine $2 A$ receptor $\left(A_{2 A} R\right)$ knockout mouse, and a combined DOCA- $A_{2 A} R^{-/}$ mouse (Ruan et al. 2018). The DOCA-salt model is commonly used to study hypertension; in 
Molecular Pharmacology Fast Forward. Published on December 21, 2021 as DOI: 10.1124/molpharm.121.000328

This article has not been copyedited and formatted. The final version may differ from this version.

\section{Heartwarming Effect of BAT}

this model, DOCA is administered to the animal (50mg/pellet) creating an imbalance of renal sodium handling with a high-salt diet [1\% $\mathrm{NaCl}$ in drinking water (Ruan et al. 2018)] incorporated to increase the onset of hypertension (Basting and Lazartigues 2017). Adenosine is a central nervous system neuromodulator and initiates vasodilation when it binds to the $A_{2 A} R$ (Khayat and Nayeem 2017); thus $A_{2 A} R$ knockout $\left[A_{2 A} R^{-1}\right]$ mice exhibit high blood pressure (Ledent et al. 1997). Unsurprisingly, DOCA- $A_{2 A} R^{-/}$mice had accelerated cardiac remodeling (fibrosis and hypertrophy) compared to WT DOCA-hypertensive mice (Ruan et al. 2018). Interestingly, $A_{2 A} R^{-/}$mice had dysfunctional interscapular BAT (BAT) demonstrated by reduced Ucp1, Pparg, Prdm16 and Cidea gene expression. Additionally, surgical depletion of iBAT accelerated cardiac hypertrophy in WT DOCA-hypertensive mice, but not in $A_{2 A} R^{-/}$ hypertensive mice. Together, these data indicate impaired BAT contributes to salt-induced hypertension and cardiac dysfunction; and suggest a role for BAT to attenuate hypertensioninduced cardiac hypertrophy via $\mathrm{A}_{2 \mathrm{~A}}$ receptors (Ruan et al. 2018).

To further elucidate the relationship between BAT and hypertension, a recent study utilized $\operatorname{Prdm}_{16}{ }^{f / f}$ AdipoCre ${ }^{+}$mice. The Prdm16 ${ }^{f / f}$ AdipoCre $^{+}$mouse was investigated based on transcriptomic profiling indicating that murine beige fat closely approximates the inducible brown fat detected by PET/CT in adult humans (Becher et al. 2020). PRDM16 is the master regulator of beiging and a coregulator of brown adipocyte development, and mice deficient in adipose tissue PRDM16 are unable to induce browning in their WAT (Cohen et al. 2014). Additionally, the white and brown adipose tissue of $\operatorname{Prdm}_{16} 6^{f / f}$ AdipoCre $^{+}$mice have severely reduced thermogenic function (Cohen et al. 2014; Harms et al. 2014). Blood pressure was elevated in adipocyte specific Prdm16 ${ }^{f / f}$ AdipoCre ${ }^{+}$mice compared to WT animals (Becher et al. 2020). Mesenteric arteries isolated from $\operatorname{Prdm}_{16} 6^{f / f}$ AdipoCre $^{+}$mice had increased contraction in response to angiotensin II treatment, suggesting the hypertension in these animals was the result of increased arterial sensitivity to angiotensin II (Becher et al. 2020). 
Molecular Pharmacology Fast Forward. Published on December 21, 2021 as DOI: 10.1124/molpharm.121.000328

This article has not been copyedited and formatted. The final version may differ from this version.

\section{Heartwarming Effect of BAT}

Together, these studies indicate that a role for beige and BAT to mediate hypertension (via $\mathrm{A}_{2 \mathrm{~A}}$ receptors and angiotensin II type 1 receptors within the vasculature) and cardiac remodeling, thus identifying BAT as a potential tool to combat hypertension.

\subsection{Myocardial infarction}

Myocardial infarction (MI) commonly results from CAD, as the arterial walls thicken and plaque blocks or slows the blood flow through the coronary arteries, cell death occurs in that area of the heart (Prabhu and Frangogiannis 2016). The necrotized myocardium is eventually replaced with fibrosis, resulting in impaired cardiac systolic and diastolic function (Prabhu and Frangogiannis 2016), often culminating in heart failure. A recent study in humans found that higher BAT activity (measured by 18FDG/PET/CT) was associated with fewer cardiovascular events, including cardiac arrest and Ml, in both male and female patients (Takx et al. 2016). While these human studies indicate a protective role for BAT against CVD, it is unclear whether the correlation between BAT and reduced CVD risk is direct or an indirect response due to improved metabolic health in these individuals.

Rodent studies have indicated that BAT has a direct role to minimize cardiac injury size in response to MI. WT mice have been shown to have increased Ucp1 levels in BAT after MI, indicating BAT activation (Thoonen et al. 2015). To elucidate the role of BAT in cardiac recovery and repair after $\mathrm{MI}, \mathrm{Ucp}_{1 \%}$ and WT mice underwent catecholamine-induced (isoproterenol) cardiomyopathy (Thoonen et al. 2015). Ucp $1^{-/}$mice had a more significant increase in cardiac fibrosis and hypertrophy, higher mortality rates, and a larger decrease in fractional shortening in response to fourteen days of isoproterenol treatment compared to WT mice.

Importantly, transplantation of WT BAT into Ucp ${ }^{1 /}$ mice reduced myocardial injury size and increased mouse survival, while transplantation of Ucp $1^{-1-}$ BAT into either Ucp $1^{-1}$ or WT mice did not have protective effects. Additionally, the isoproterenol treatment was correlated with an increase in phosphorylation of AKT and ERK1/2 in the left-ventricle of WT mice, but not Ucp ${ }^{-1}$ mice. This is important because ERK1/2 and AKT are cardioprotective in ischemia-reperfusion 
Molecular Pharmacology Fast Forward. Published on December 21, 2021 as DOI: 10.1124/molpharm.121.000328

This article has not been copyedited and formatted. The final version may differ from this version.

\section{Heartwarming Effect of BAT}

injury models (Murphy and Steenbergen 2008; van Berlo, Maillet, and Molkentin 2013), suggesting that the cardioprotective effect of the AKT-ERK1/2 pathway in mice after catecholamine-induced cardiomyocyte injury may require BAT activation. These data indicate that BAT thermogenic activity is vital for cardiac repair after MI. Future studies are required to fully define the pathway of BAT activated AKT-ERK1/2 to determine targets for potential MI therapies.

\section{Batokines}

While several studies have focused on the thermogenic role of BAT, BAT also has an important endocrine function which can mediate systemic health benefits (Ahmad et al. 2021; Lee, Lee, and Oh 2019; Villarroya et al. 2019). BAT releases signaling molecules, such as lipids, proteins metabolites or microRNAs, which can be broadly categorized as 'batokines' that act on other tissues and organs. These batokines have significant effects on systemic metabolism, and more recently have been identified to play a role in cardiac health (Figure 1, Table 1). Here, we will focus primarily on the batokines with a role in cardiovascular health and function.

\subsection{IL-6}

Interleukin 6 (IL-6) is a protein which acts as both a pro-inflammatory cytokine and an antiinflammatory myokine. It is important to note that the tissue source of IL-6 influences the nature its action (Han et al. 2020). Specifically, IL-6 has been identified as a batokine that mediates the improved metabolic response after BAT transplantation in mice (Stanford et al. 2013). BAT transplantation increased insulin-stimulated glucose uptake in vivo into endogenous BAT, WAT, and heart muscle. However, when BAT was transplanted from $I L 6^{-/}$mice into WT mice, these beneficial effects on metabolism were lost, demonstrating that BAT-derived IL-6 is required for the profound effects of BAT transplantation on glucose homeostasis and insulin sensitivity. In support of these data, an increase of IL-6 by gene transfer (hydrodynamic delivery of $1 \mu \mathrm{g}$ pLIVE-IL6 plasmid) reverses weight gain and hepatic steatosis in obese mice (Ma et al. 2015). 
Molecular Pharmacology Fast Forward. Published on December 21, 2021 as DOI: 10.1124/molpharm.121.000328

This article has not been copyedited and formatted. The final version may differ from this version.

\section{Heartwarming Effect of BAT}

IL6 also has a role in thermoregulation. Body temperature is decreased in total body $I L 6^{-1-}$ mice and central nervous systemic specific IL6 receptor a [IL6Ra] knockdown (IL6Ra ${ }^{\mathrm{NeSC} C \mathrm{e}}$ ) mice, indicating impaired thermogenesis in these animals (Egecioglu et al. 2018). However, the effects of IL-6 on the heart are unclear; when IL-6 is produced acutely it is protective against MI or ischemia injury in rodents (Chandrasekar et al. 1999; YamauchiTakihara et al. 1995), but when chronically released, IL-6 causes pathologic cardiac hypertrophy and impaired cardiomyocyte contraction (Wollert et al. 1996; Terrell et al. 2006; Prabhu 2004). It is important to note, however, that these studies were specifically examining the effects of cardiomyocyte-derived IL-6, therefore the effects of BAT-derived IL-6 on cardiac function remain elusive. Further studies are needed to elucidate if BAT-derived IL-6 batokine action on cardiac function.

\subsection{FGF21}

FGF21 is a metabolic regulator released from several organs, including the liver and BAT. FGF21 is highly expressed in human BAT (Di Franco et al. 2016) with circulating levels increased upon cold exposure (Lee et al. 2014) via activation of the c-AMP pathways (Hondares et al. 2011).

Although the role of FGF21 in human cardiovascular disease has not been investigated, it has been shown to have both antihypertrophic and cardioprotective actions in mouse models of hypertension (Ruan et al. 2018), hypertrophy (Planavila et al. 2013; Ruan et al. 2018) and ischemia (Liu et al. 2013).

Mouse studies have shown that $F g f 21^{-/}$animals have increased heart weight, enhanced dilatation and cardiac dysfunction compared to WT mice in response to isoproterenol infusion, indicating development of pathological hypertrophy, a sign of heart failure (Planavila et al. 2013). Conversely, FGF21 has been shown to be upregulated in response to myocardial injury (in liver and WAT), with FGF receptor cofactor $\beta$-Klotho upregulated in cardiomyocytes for 5 days post-MI (Liu et al. 2013). FGF21 has been determined to interact with FGF receptor 1 in 
Molecular Pharmacology Fast Forward. Published on December 21, 2021 as DOI: 10.1124/molpharm.121.000328

This article has not been copyedited and formatted. The final version may differ from this version.

\section{Heartwarming Effect of BAT}

cardiomyocytes, and to induce $\mathrm{PI} 3 \mathrm{~K}$ phosphorylation activating a cardioprotective signaling pathway. While these effects on cardiac function are clearly mediated by FGF21, the role of BAT-released FGF21 was not specifically addressed.

A study using hypertensive mouse models (WT DOCA-salt sensitive mice, adenosine 2A receptor $\left(A_{2 A} R\right)$ knockout mice, and DOCA- $\mathrm{A}_{2 A} \mathrm{R}^{-/-}$mice) has confirmed the role of batokine FGF21 in cardiovascular health (Ruan et al. 2018). Surgical removal of BAT in WT, DOCAhypertensive mice resulted in reduced serum FGF21 levels and increased cardiac remodeling, however these effects were absent in $A_{2 A} R^{-/}$mice (Ruan et al. 2018). Importantly, recombinant FGF21 treatment prevented these adverse effects in iBAT-depleted DOCA-hypertensive mice. Further investigation revealed that CGS21680 ( $A_{2 A} R$ agonist) promotes FGF21 expression and release in brown adipocytes, whereas $\mathrm{KW6002}\left(\mathrm{A}_{2 \mathrm{~A}} \mathrm{R}\right.$ antagonist) inhibits the release of FGF21 from BAT (Ruan et al. 2018). Additionally, FGF21 expression was decreased in $A_{2 A} R^{-/}$brown adipocytes compared to WT brown adipocytes. These data show $A_{2 A} R$ activation may induce the release of BAT-derived FGF21, resulting in reduced cardiac hypertrophy in response to hypertension.

\subsection{2-HEPE}

Oxylipins are lipid metabolites of polyunsaturated fatty acids (PUFAs) and act as signaling molecules. There are several oxylipins known to be released from BAT, some of which have beneficial effects on metabolic and cardiac health. 12-HEPE is derived from arachidonate 12lipoxygenase (12-LOX), which catalyzes the oxidation of PUFAs, and has recently been identified to be released from BAT in response to cold and $\beta 3$-adrenergic stimulation. Both cold and $\beta_{3}$-adrenergic stimulation promote biosynthesis and release of 12-LOX metabolites from BAT (Leiria et al. 2019). 12-HEPE improves glucose metabolism by promoting the PI3K/Akt/Glut pathway and stimulating glucose uptake into adipocytes and skeletal muscle in a mouse model (Leiria et al. 2019). Although not yet studied in the context of cardiovascular function, 12-HEPE 
Molecular Pharmacology Fast Forward. Published on December 21, 2021 as DOI: 10.1124/molpharm.121.000328

This article has not been copyedited and formatted. The final version may differ from this version.

\section{Heartwarming Effect of BAT}

represents an exciting potential for BAT activity to regulate metabolic health, and, in turn, reduce risk factors for CVD.

\subsection{2,13-diHOME}

The linoleic acid derivative 12,13-diHOME is a batokine that is released in mice and humans in response to cold (Lynes et al. 2017) and exercise (Stanford et al. 2018). Mouse studies show 12,13-diHOME increases FA uptake into brown adipocytes, skeletal muscle, and cardiomyocytes (Lynes et al. 2017; Stanford et al. 2018; Pinckard et al. 2021). Studies in humans have shown that 12,13-diHOME is correlated with reduced fat mass, fasting insulin, TGs, improved mitochondrial function, and is increased after an acute bout of exercise in both male and female subjects (Stanford et al. 2018; Lynes et al. 2017; Nayor et al. 2020; Vasan et al. 2019).

Recent work from our laboratory investigated the effects of increasing BAT by transplantation on cardiac function and determined that increasing BAT improved in vivo cardiac hemodynamics and remodeling in mice (Pinckard et al. 2021). To determine the mechanism behind these cardiac improvements, non-targeted lipidomics were performed and revealed 12,13-diHOME to be significantly upregulated in mice after BAT transplantation. Acute injection of 12,13-diHOME improved systolic and diastolic function, similar to the effects of increasing BAT. Further investigation revealed a direct role for 12,13-diHOME to increase cardiomyocyte function (shortening, kinetics and calcium cycling) and mitochondrial respiration. Sustained overexpression of 12,13-diHOME via tissue nano-transfection (TNT) of mice fed a high-fat diet (HFD) prevented HFD-induced impairments on cardiac function, suggesting potential translatability of 12,13-diHOME as a clinical treatment for CVD. In humans, both male and female patients with cardiovascular disease had reduced circulating levels of 12,13-diHOME compared to healthy individuals. Taken together, our data suggest that the beneficial cardiac adaptions of BAT are dependent on 12,13-diHOME, providing a possible translatable therapeutic for CVD. 
Molecular Pharmacology Fast Forward. Published on December 21, 2021 as DOI: 10.1124/molpharm.121.000328

This article has not been copyedited and formatted. The final version may differ from this version.

\section{Heartwarming Effect of BAT}

Together these studies indicate that in addition to its thermogenic role, the endocrine function of BAT (specifically IL6, FGF21 and 12-13-diHOME) can have vast systemic effects on metabolism and cardiac health. Importantly, the role of these batokines in cardiac disease (atherosclerosis, hypertension, and MI) have not been extensively investigated but will likely be an avenue of future investigation.

\section{Pharmacological strategies}

BAT has significant potential as a preventive and therapeutic tool against CVD. However, BAT mass and activity decrease with increasing CVD risk factors including BMI, insulin resistance, and age (Zoico et al. 2019; Cypess et al. 2009; Vijgen et al. 2011). In order to utilize BAT for disease prevention and treatment, translational approaches aimed towards increasing BAT mass/activity or mimicking BAT endocrine function must be addressed. Because of this, recent studies have focused on pharmacological agents that activate BAT; here we will discuss their effects on CVD.

\section{$5.1 \beta_{3}$-adrenergic activators}

As a potent activator of BAT in both rodents and humans, sympathetic activation as a possible therapeutic for metabolic diseases has been an area of investigation for several years. However, there have been varying results as to the effectiveness of these treatments, possibly due to the specific focus on $\beta_{3}$-AR agonists, rather than $\beta_{1}$ - and $\beta_{2}$-ARs, which are the primary regulators of BAT activity in humans (Riis-Vestergaard et al. 2020; Blondin et al. 2020). In mice, long-term treatment with $\beta_{3}$-AR agonist or thyroid hormone, both recognized BAT activators, lowers plasma lipid and glucose levels (Peirce and Vidal-Puig 2013; Wang, Li, and Guo 2013). Mirabegron, a $\beta_{3}$-adrenergic receptor agonist, which has been shown to stimulate BAT glucose uptake in humans (Baskin et al. 2018), is of particular interest. Several other $\beta_{3}$-adrenergic agonists have been investigated in both rodent studies and humans but have shown minimal benefits, and therefore are not current topics of interest (Mukherjee, Baranwal, and Schade 2016). 
Molecular Pharmacology Fast Forward. Published on December 21, 2021 as DOI: 10.1124/molpharm.121.000328

This article has not been copyedited and formatted. The final version may differ from this version.

\section{Heartwarming Effect of BAT}

A recent paper by O'Mara, et al showed that chronic mirabegron treatment increases BAT thermogenesis, improves glucose effectiveness and insulin sensitivity in healthy women. Women who had less BAT mass/activity before treatment showed greater increases in both glucose effectiveness and insulin sensitivity compared to women who started with more BAT mass/activity (O'Mara et al. 2020). Additionally, patients who underwent mirabegron treatment had increased fasting HDL levels and a lower ApoB/ApoA1 ratio (a biomarker of cardiovascular risk), suggesting the mirabegron treatment may provide some cardiovascular benefits. In a separate study, mirabegron also improved glucose tolerance, insulin sensitivity and beta cell function in obese, insulin resistant males and females (Finlin et al. 2020). These data suggest mirabegron treatment has several beneficial effects, including increased BAT mass and activity, improved glucose tolerance and insulin sensitivity, and improved cholesterol profile.

It is important to note that long-term SNS activation by drugs such as mirabegron increase blood pressure, potentially accelerating the risk for development of cardiac overload or heart failure (Zhang and Anderson 2014; Mancia and Grassi 2014). The O'Mara study showed mirabegron treatment caused both an acute and sustained increase in resting heart rate, systolic blood pressure, and rate-pressure product (an indirect measurement of myocardial oxygen consumption), indicating chronic adrenergic stimulation. These data indicate a promising role for BAT activators to improve cardiovascular health, but more work is required to determine the potential side effects of mirabegron and other $\beta$-AR agonists.

\subsection{Norepinephrine reuptake inhibition}

Inhibition of norepinephrine (NE) reuptake can also increase BAT activity. Atomoxetine is a drug used clinically for attention deficit hyperactivity disorder treatment in humans, but has also been shown to increase glucose uptake of BAT in fasted rats (Mirbolooki et al. 2013). In mice, atomoxetine activation of BAT was associated with higher BAT temperature and lower blood glucose, indicating therapeutic potential. In humans, atomoxetine treatment has been shown to contribute to modest weight loss in adolescents (Wernicke and Kratochvil 2002), and 
Molecular Pharmacology Fast Forward. Published on December 21, 2021 as DOI: 10.1124/molpharm.121.000328

This article has not been copyedited and formatted. The final version may differ from this version.

\section{Heartwarming Effect of BAT}

obese adult women with obesity (Gadde et al. 2006). However, this drug has similar side effects as SNS activators on cardiac health including increased heart rate and blood pressure in humans (Habel et al. 2011).

\subsection{Indirubin}

A recent study used connectivity mapping to identify a drug to study BAT activation focusing on Ucp1 upregulation rather than SNS activation (Wei et al. 2020). The drug, indirubin, is currently used for treatment of chronic myelogenous leukemia. Indirubin incubation increased mitochondrial respiration in C3H10T1/2 cells differentiated into adipocytes; and injection protected against HFD-induced weight gain, glucose-intolerance, and fatty liver in WT mice. Immunohistochemistry and gene expression analysis indicated that these improvements were in response to increased BAT thermogenic activity (Ucp1, Pgc1a, Prdm16, Dio2, Elovl3, Cidea, $H s$ ). However, no cardiac parameters were investigated in this study; determining if indirubin protects against HFD-induced cardiovascular dysfunctions in mice is an important area of future investigation.

\section{Discussion}

There is significant evidence for increased BAT mass or activity as a potential therapeutic target for the prevention and treatment of obesity and other metabolic diseases (Stanford et al. 2013; Liu et al. 2015; Thoonen et al. 2015), and in this review we discuss the growing evidence supporting a role for BAT as a therapeutic target for cardiovascular diseases (Berbee et al. 2015; Thoonen, Hindle, and Scherrer-Crosbie 2016; Thoonen et al. 2015). Increased BAT mass or activation in mice consistently results in dramatic improvements in cardiovascular health; this includes reduction of atherosclerotic region, reduced myocardial injury size, and direct improvements on cardiac systolic and diastolic function (Berbee et al. 2015; Ruan et al. 2018; Thoonen et al. 2015; Pinckard et al. 2021). These benefits are partially mediated by increased thermogenic function of BAT, specifically in the case of atherosclerosis and MI: BAT activation accelerates hepatic clearance of cholesterol-enriched remnants (Berbee et al. 2015), improves 
Molecular Pharmacology Fast Forward. Published on December 21, 2021 as DOI: 10.1124/molpharm.121.000328

This article has not been copyedited and formatted. The final version may differ from this version.

\section{Heartwarming Effect of BAT}

TG clearance from the blood stream, and increases activation of the AKT-ERK1/2 pathways during myocardial injury (Thoonen et al. 2015). Additionally, several studies have now highlighted the endocrine action of BAT to protect against cardiovascular dysfunction and to act directly upon cardiomyocytes to improve cardiac systolic and diastolic function, including through the release of FGF21 and 12,13-diHOME (Ruan et al. 2018; Pinckard et al. 2021).

As cardiovascular diseases continue to be the number one cause of death across the globe, novel methods for preventing and treating these diseases are vital (Benjamin EJ 2018; Prevention 2017; Blacks 2018). Several studies highlight the ability of BAT to mediate cardiac function. However, BAT mass and activity decreases with increasing age and BMI; two top risk factors for CVD, highlighting the need for further investigation on the role of BAT and cardiac function in an aged population (Zoico et al. 2019; Cypess et al. 2009; Vijgen et al. 2011). It is additionally important to note that several of the animal studies discussed in this review only investigated male mice. This is an important omission since, while functional BAT can be detected upon stimulation in $>50 \%$ of adults (Cronin et al. 2012; Cypess et al. 2009; Ouellet et al. 2011), young lean women have been shown to possess BAT at a higher percentage compared to young, lean men (Ouellet et al. 2011). Thus, future studies should utilize mouse models of both sexes to fully understand the potential sexual dimorphisms seen with BAT mass and activation.

The data summarized in this review indicate highlight that both the thermogenic and endocrine function of BAT play an important role in cardiovascular health. Importantly, these studies expand on previous data by showing that BAT improves cardiovascular health not only by improving systemic metabolism (Wang, Zhao, and Lin 2015), clearing lipids from the bloodstream (Wang, Zhang, et al. 2015; Stanford et al. 2013), and reducing obesity (Thoonen, Hindle, and Scherrer-Crosbie 2016; Peres Valgas da Silva et al. 2019), but also by activating cardioprotective pathways (Berbee et al. 2015; Thoonen et al. 2015), and directly affecting cardiomyocyte function (Pinckard et al. 2021). As a relatively new field, there is a lot to learn 
Molecular Pharmacology Fast Forward. Published on December 21, 2021 as DOI: 10.1124/molpharm.121.000328

This article has not been copyedited and formatted. The final version may differ from this version.

\section{Heartwarming Effect of BAT}

about the effects of BAT on cardiovascular function, specifically with regard to the endocrine role of BAT and batokines.

Increased sympathetic activation of BAT poses a possible therapeutic method, however long-term SNS activation is known to increase blood pressure and risk of heart failure (Zhang and Anderson 2014; Mancia and Grassi 2014). Mirabegron ( $\beta_{3}$-adrenergic receptor agonist) has confounding results in terms of cardiovascular risks/benefits; treatment increased resting heart rate, systolic blood pressure, and rate-pressure product, however these patients also had increased $\mathrm{HDL}$ levels and reduced ApoB/A1 ratio (O'Mara et al. 2020). A possible method to bypass the off-target effects of SNS activation is the use of direct batokines as therapeutics, several of which have been shown to have cardioprotective effects when treated exogenously in mice. To our knowledge, no studies to date have investigated the efficacy of batokine treatment in humans.

In summary, BAT has exciting potential to prevent CVD through both its thermogenic and endocrine functions (via batokines). Thermogenic BAT activity increases TG clearance from the bloodstream, accelerates hepatic clearance of cholesterol-enriched remnants, improves TG clearance from the blood stream, and activates the protective AKT-ERK1/2 pathway during myocardial injury (Berbee et al. 2015; Thoonen et al. 2015). $A_{2 A} R$-induced release of the batokine FGF21 results in reduced cardiac hypertrophy in response to hypertension, while the cold and exercise induced batokine 12,13-diHOME directly improves cardiac systolic and diastolic function via increased calcium cycling in cardiomyocytes (Ruan et al. 2018; Pinckard et al. 2021). Sympathetic activation of BAT via $\beta_{3}-A R$ agonists have been investigated as therapeutics for metabolic and cardiovascular diseases with varying results, however targeting $\beta_{1}$ or $\beta_{2}$-ARs (rather than $\beta_{3}$ ) may be more effective at activating BAT in humans. Regardless, more research on the side effects of SNS-activators is warranted, as sustained SNS activation can cause undesirable cardiovascular effects. Future research may consider batokines or other 
Molecular Pharmacology Fast Forward. Published on December 21, 2021 as DOI: 10.1124/molpharm.121.000328

This article has not been copyedited and formatted. The final version may differ from this version.

Heartwarming Effect of BAT

BAT mimetics as therapeutic methods to elucidate the beneficial effects of BAT on CVD, rather

than SNS-agonists.

Financial Disclosure: This work was supported by National Institutes of Health Grants R01HL138738 and R01-AG060542 to K.I.S., and 1F31HL152648-01A1 to K.M.P.

\section{Author contributions:}

KMP and KIS designed, wrote, and edited the manuscript.

Figure 1: Brown adipose tissue mediates cardiac function via thermogenic and endocrine action.

Abbreviations: $\beta$-AR: $\beta$-adrenergic receptors; iBAT: intrascapular brown adipose tissue; TAG: triacylglycerol; FA: fatty acid; ERK: extracellular-signal-regulated kinase; AKT: protein kinase B; IL6: interleukin 6; FGF21: fibroblast growth factor 21; CM: cardiomyocyte.

\section{Literature Cited}

Ahmad, B., M. S. Vohra, M. A. Saleemi, C. J. Serpell, I. L. Fong, and E. H. Wong. 2021. 'Brown/Beige adipose tissues and the emerging role of their secretory factors in improving metabolic health: The batokines', Biochimie, 184: 26-39.

Bakker, L. E., M. R. Boon, R. A. van der Linden, L. P. Arias-Bouda, J. B. van Klinken, F. Smit, H. J. Verberne, J. W. Jukema, J. T. Tamsma, L. M. Havekes, W. D. van Marken Lichtenbelt, I. M. Jazet, and P. C. Rensen. 2014. 'Brown adipose tissue volume in healthy lean south Asian adults compared with white Caucasians: a prospective, case-controlled observational study', Lancet Diabetes Endocrinol, 2: 210-7. Baskin, A. S., J. D. Linderman, R. J. Brychta, S. McGehee, E. Anflick-Chames, C. Cero, J. W. Johnson, A. E. O'Mara, L. A. Fletcher, B. P. Leitner, C. J. Duckworth, S. Huang, H. Cai, H. M. Garraffo, C. M. Millo, W. Dieckmann, V. Tolstikov, E. Y. Chen, F. Gao, N. R. Narain, M. A. Kiebish, P. J. Walter, P. Herscovitch, K. Y. Chen, and A. M. Cypess. 2018. 'Regulation of Human Adipose Tissue Activation, Gallbladder Size, and Bile Acid Metabolism by a beta3-Adrenergic Receptor Agonist', Diabetes, 67: 2113-25.

Basting, T., and E. Lazartigues. 2017. 'DOCA-Salt Hypertension: an Update', Curr Hypertens Rep, 19: 32. Becher, T., S. Palanisamy, D. J. Kramer, M. Eljalby, S. J. Marx, A. G. Wibmer, S. D. Butler, C. S. Jiang, R. Vaughan, H. Schoder, A. Mark, and P. Cohen. 2021. 'Brown adipose tissue is associated with cardiometabolic health', Nat Med, 27: 58-65.

Becher, Tobias, Srikanth Palanisamy, Daniel J. Kramer, Sarah J. Marx, Andreas G. Wibmer, Ilaria Del Gaudio, Scott D. Butler, Caroline S. Jiang, Roger Vaughan, Heiko Schöder, Annarita Di Lorenzo, Allyn Mark, and Paul Cohen. 2020. 'Brown Adipose Tissue is Associated with Improved Cardiometabolic Health and Regulates Blood Pressure', bioRxiv: 2020.02.08.933754.

Benjamin EJ, Virani SS, Callaway CW, Chang AR, Cheng S, Chiuve SE, Cushman M, Delling FN, Deo R, de Ferranti SD, Ferguson JF, Fornage M, Gillespie C, Isasi CR, Jimenez MC, Jordan LC, Judd SE, Lackland D, Lichtman JH, Lisabeth L, Liu S, Longenecker CT, Lutsey PL, Matchar DB, Matsushita K, Mussolino ME, Nasir K, O'Flaherty M, Palaniappan LP, Pandey DK, Reeves MJ, Ritchey MD, Rodriguez CJ, Roth GA, Rosamond WD, Sampson UKA, Satou GM, Shah SH, Spartano NL, Tirschwell DL, Tsao CW, Voeks JH, Willey JZ, Wilkins JT, Wu JHY, Alger HM, Wong SS, Muntner P; on behalf of the 
Molecular Pharmacology Fast Forward. Published on December 21, 2021 as DOI: 10.1124/molpharm.121.000328

This article has not been copyedited and formatted. The final version may differ from this version.

\section{Heartwarming Effect of BAT}

American Heart Association Council on Epidemiology and Prevention Statistics Committee and Stroke Statistics Subcommittee. 2018. "Heart Disease and Stroke Statistics 2018 At-a-Glance." In. American Heart Association.

Berbee, J. F., M. R. Boon, P. P. Khedoe, A. Bartelt, C. Schlein, A. Worthmann, S. Kooijman, G. Hoeke, I. M. Mol, C. John, C. Jung, N. Vazirpanah, L. P. Brouwers, P. L. Gordts, J. D. Esko, P. S. Hiemstra, L. M. Havekes, L. Scheja, J. Heeren, and P. C. Rensen. 2015. 'Brown fat activation reduces hypercholesterolaemia and protects from atherosclerosis development', Nat Commun, 6: 6356. Betz, M. J., and S. Enerback. 2015. 'Human Brown Adipose Tissue: What We Have Learned So Far', Diabetes, 64: 2352-60.

Blacks, NH 2018. 'Heart Disease Statistics and Maps', Accessed January 6.

Blondin, D. P., S. Nielsen, E. N. Kuipers, M. C. Severinsen, V. H. Jensen, S. Miard, N. Z. Jespersen, S. Kooijman, M. R. Boon, M. Fortin, S. Phoenix, F. Frisch, B. Guerin, E. E. Turcotte, F. Haman, D. Richard, F. Picard, P. C. N. Rensen, C. Scheele, and A. C. Carpentier. 2020. 'Human Brown Adipocyte Thermogenesis Is Driven by beta2-AR Stimulation', Cell Metab, 32: 287-300 e7.

Burysek, L., and J. Houstek. 1997. 'beta-Adrenergic stimulation of interleukin-1alpha and interleukin-6 expression in mouse brown adipocytes', FEBS Lett, 411: 83-6.

Campderros, L., R. Moure, M. Cairo, A. Gavalda-Navarro, T. Quesada-Lopez, R. Cereijo, M. Giralt, J. Villarroya, and F. Villarroya. 2019. 'Brown Adipocytes Secrete GDF15 in Response to Thermogenic Activation', Obesity (Silver Spring), 27: 1606-16.

Cannon, B., J. M. A. de Jong, A. W. Fischer, J. Nedergaard, and N. Petrovic. 2020. 'Human brown adipose tissue: Classical brown rather than brite/beige?', Exp Physiol, 105: 1191-200.

Cannon, B., and J. Nedergaard. 2004. 'Brown adipose tissue: function and physiological significance', Physiol Rev, 84: 277-359.

Carbone, S., J. M. Canada, H. E. Billingsley, M. S. Siddiqui, A. Elagizi, and C. J. Lavie. 2019. 'Obesity paradox in cardiovascular disease: where do we stand?', Vasc Health Risk Manag, 15: 89-100.

Carpentier, A. C., D. P. Blondin, K. A. Virtanen, D. Richard, F. Haman, and E. E. Turcotte. 2018. 'Brown Adipose Tissue Energy Metabolism in Humans', Front Endocrinol (Lausanne), 9: 447.

Cereijo, R., A. Gavalda-Navarro, M. Cairo, T. Quesada-Lopez, J. Villarroya, S. Moron-Ros, D. SanchezInfantes, M. Peyrou, R. Iglesias, T. Mampel, J. V. Turatsinze, D. L. Eizirik, M. Giralt, and F. Villarroya. 2018. 'CXCL14, a Brown Adipokine that Mediates Brown-Fat-to-Macrophage Communication in Thermogenic Adaptation', Cell Metab, 28: 750-63 e6.

Cero, C., H. J. Lea, K. Y. Zhu, F. Shamsi, Y. H. Tseng, and A. M. Cypess. 2021. 'beta3-Adrenergic receptors regulate human brown/beige adipocyte lipolysis and thermogenesis', JCI Insight, 6. Chandrasekar, B., D. H. Mitchell, J. T. Colston, and G. L. Freeman. 1999. 'Regulation of CCAAT/Enhancer binding protein, interleukin-6, interleukin-6 receptor, and gp130 expression during myocardial ischemia/reperfusion', Circulation, 99: 427-33.

Chen, Z., G. X. Wang, S. L. Ma, D. Y. Jung, H. Ha, T. Altamimi, X. Y. Zhao, L. Guo, P. Zhang, C. R. Hu, J. X. Cheng, G. D. Lopaschuk, J. K. Kim, and J. D. Lin. 2017. 'Nrg4 promotes fuel oxidation and a healthy adipokine profile to ameliorate diet-induced metabolic disorders', Mol Metab, 6: 863-72.

Christian, M. 2015. 'Transcriptional fingerprinting of "browning" white fat identifies NRG4 as a novel adipokine', Adipocyte, 4: 50-4.

Cohen, P., J. D. Levy, Y. Zhang, A. Frontini, D. P. Kolodin, K. J. Svensson, J. C. Lo, X. Zeng, L. Ye, M. J. Khandekar, J. Wu, S. C. Gunawardana, A. S. Banks, J. P. Camporez, M. J. Jurczak, S. Kajimura, D. W. Piston, D. Mathis, S. Cinti, G. I. Shulman, P. Seale, and B. M. Spiegelman. 2014. 'Ablation of PRDM16 and beige adipose causes metabolic dysfunction and a subcutaneous to visceral fat switch', Cell, 156: 304-16.

Cronin, C. G., P. Prakash, G. H. Daniels, G. W. Boland, M. K. Kalra, E. F. Halpern, E. L. Palmer, and M. A. Blake. 2012. 'Brown fat at PET/CT: correlation with patient characteristics', Radiology, 263: 836-42. Cypess, A. M., and C. R. Kahn. 2010. 'Brown fat as a therapy for obesity and diabetes', Curr Opin Endocrinol Diabetes Obes, 17: 143-9.

Cypess, A. M., S. Lehman, G. Williams, I. Tal, D. Rodman, A. B. Goldfine, F. C. Kuo, E. L. Palmer, Y. H. Tseng, A. Doria, G. M. Kolodny, and C. R. Kahn. 2009. 'Identification and importance of brown adipose tissue in adult humans', N Engl J Med, 360: 1509-17.

Cypess, A. M., A. P. White, C. Vernochet, T. J. Schulz, R. Xue, C. A. Sass, T. L. Huang, C. RobertsToler, L. S. Weiner, C. Sze, A. T. Chacko, L. N. Deschamps, L. M. Herder, N. Truchan, A. L. Glasgow, A. R. Holman, A. Gavrila, P. O. Hasselgren, M. A. Mori, M. Molla, and Y. H. Tseng. 2013. 'Anatomical 
Molecular Pharmacology Fast Forward. Published on December 21, 2021 as DOI: 10.1124/molpharm.121.000328

This article has not been copyedited and formatted. The final version may differ from this version.

\section{Heartwarming Effect of BAT}

localization, gene expression profiling and functional characterization of adult human neck brown fat', Nat Med, 19: 635-9.

de Jesus, L. A., S. D. Carvalho, M. O. Ribeiro, M. Schneider, S. W. Kim, J. W. Harney, P. R. Larsen, and A. C. Bianco. 2001. 'The type 2 iodothyronine deiodinase is essential for adaptive thermogenesis in brown adipose tissue', J Clin Invest, 108: 1379-85.

DeMambro, V. E., L. Maile, C. Wai, M. Kawai, T. Cascella, C. J. Rosen, and D. Clemmons. 2012. 'Insulinlike growth factor-binding protein-2 is required for osteoclast differentiation', J Bone Miner Res, 27: 390400.

Deshmukh, A. S., L. Peijs, J. L. Beaudry, N. Z. Jespersen, C. H. Nielsen, T. Ma, A. D. Brunner, T. J. Larsen, R. Bayarri-Olmos, B. S. Prabhakar, C. Helgstrand, M. C. K. Severinsen, B. Holst, A. Kjaer, M. Tang-Christensen, A. Sanfridson, P. Garred, G. G. Prive, B. K. Pedersen, Z. Gerhart-Hines, S. Nielsen, D. J. Drucker, M. Mann, and C. Scheele. 2019. 'Proteomics-Based Comparative Mapping of the Secretomes of Human Brown and White Adipocytes Reveals EPDR1 as a Novel Batokine', Cell Metab, 30: 963-75 e7.

Di Franco, A., D. Guasti, R. Squecco, B. Mazzanti, F. Rossi, E. Idrizaj, J. M. Gallego-Escuredo, F. Villarroya, D. Bani, G. Forti, G. B. Vannelli, and M. Luconi. 2016. 'Searching for Classical Brown Fat in Humans: Development of a Novel Human Fetal Brown Stem Cell Model', Stem Cells, 34: 1679-91. Duchamp, C., K. A. Burton, A. Geloen, and M. J. Dauncey. 1997. 'Transient upregulation of IGF-I gene expression in brown adipose tissue of cold-exposed rats', Am J Physiol, 272: E453-60.

Egecioglu, E., F. Anesten, E. Schele, and V. Palsdottir. 2018. 'Interleukin-6 is important for regulation of core body temperature during long-term cold exposure in mice', Biomed Rep, 9: 206-12.

Esteve Rafols, M. 2014. 'Adipose tissue: cell heterogeneity and functional diversity', Endocrinol Nutr, 61: 100-12.

Finlin, B. S., H. Memetimin, B. Zhu, A. L. Confides, H. J. Vekaria, R. H. El Khouli, Z. R. Johnson, P. M. Westgate, J. Chen, A. J. Morris, P. G. Sullivan, E. E. Dupont-Versteegden, and P. A. Kern. 2020. 'The beta3-adrenergic receptor agonist mirabegron improves glucose homeostasis in obese humans', $J$ Clin Invest, 130: 2319-31.

Fournier, B., B. Murray, S. Gutzwiller, S. Marcaletti, D. Marcellin, S. Bergling, S. Brachat, E. Persohn, E. Pierrel, F. Bombard, S. Hatakeyama, A. U. Trendelenburg, F. Morvan, B. Richardson, D. J. Glass, E. Lach-Trifilieff, and J. N. Feige. 2012. 'Blockade of the activin receptor Ilb activates functional brown adipogenesis and thermogenesis by inducing mitochondrial oxidative metabolism', Mol Cell Biol, 32: 2871-9.

Fu, Z., F. Yao, A. B. Abou-Samra, and R. Zhang. 2013. 'Lipasin, thermoregulated in brown fat, is a novel but atypical member of the angiopoietin-like protein family', Biochem Biophys Res Commun, 430: 112631.

Gadde, K. M., G. M. Yonish, H. R. Wagner, 2nd, M. S. Foust, and D. B. Allison. 2006. 'Atomoxetine for weight reduction in obese women: a preliminary randomised controlled trial', Int J Obes (Lond), 30: 113842.

Gaich, G., J. Y. Chien, H. Fu, L. C. Glass, M. A. Deeg, W. L. Holland, A. Kharitonenkov, T. Bumol, H. K. Schilske, and D. E. Moller. 2013. 'The effects of LY2405319, an FGF21 analog, in obese human subjects with type 2 diabetes', Cell Metab, 18: 333-40.

Giles, D. A., B. Ramkhelawon, E. M. Donelan, T. E. Stankiewicz, S. B. Hutchison, R. Mukherjee, M. Cappelletti, R. Karns, C. L. Karp, K. J. Moore, and S. Divanovic. 2016. 'Modulation of ambient temperature promotes inflammation and initiates atherosclerosis in wild type C57BL/6 mice', Mol Metab, 5: 1121-30.

Gnad, T., S. Scheibler, I. von Kugelgen, C. Scheele, A. Kilic, A. Glode, L. S. Hoffmann, L. Reverte-Salisa, P. Horn, S. Mutlu, A. El-Tayeb, M. Kranz, W. Deuther-Conrad, P. Brust, M. E. Lidell, M. J. Betz, S. Enerback, J. Schrader, G. G. Yegutkin, C. E. Muller, and A. Pfeifer. 2014. 'Adenosine activates brown adipose tissue and recruits beige adipocytes via A2A receptors', Nature, 516: 395-9.

Gunawardana, S. C., and D. W. Piston. 2012. 'Reversal of type 1 diabetes in mice by brown adipose tissue transplant', Diabetes, 61: 674-82.

. 2015. 'Insulin-independent reversal of type 1 diabetes in nonobese diabetic mice with brown adipose tissue transplant', Am J Physiol Endocrinol Metab, 308: E1043-55.

Habel, L. A., W. O. Cooper, C. M. Sox, K. A. Chan, B. H. Fireman, P. G. Arbogast, T. C. Cheetham, V. P. Quinn, S. Dublin, D. M. Boudreau, S. E. Andrade, P. A. Pawloski, M. A. Raebel, D. H. Smith, N.

Achacoso, C. Uratsu, A. S. Go, S. Sidney, M. N. Nguyen-Huynh, W. A. Ray, and J. V. Selby. 2011. 
Molecular Pharmacology Fast Forward. Published on December 21, 2021 as DOI: 10.1124/molpharm.121.000328

This article has not been copyedited and formatted. The final version may differ from this version.

\section{Heartwarming Effect of BAT}

'ADHD medications and risk of serious cardiovascular events in young and middle-aged adults', JAMA, 306: 2673-83.

Hales CM, Carroll MD, Fryar CD, Ogden CL. 2017. "Prevalence of Obesity Among Adults and Youth: United States, 2015-2016." In U.S. Department of Health and Human Services, edited by Centers for Disease Control and Prevention.

Han, M. S., A. White, R. J. Perry, J. P. Camporez, J. Hidalgo, G. I. Shulman, and R. J. Davis. 2020. 'Regulation of adipose tissue inflammation by interleukin 6', Proc Natl Acad Sci U S A, 117: 2751-60. Harms, M. J., J. Ishibashi, W. Wang, H. W. Lim, S. Goyama, T. Sato, M. Kurokawa, K. J. Won, and P. Seale. 2014. 'Prdm16 is required for the maintenance of brown adipocyte identity and function in adult mice', Cell Metab, 19: 593-604.

Hondares, E., R. Iglesias, A. Giralt, F. J. Gonzalez, M. Giralt, T. Mampel, and F. Villarroya. 2011. 'Thermogenic activation induces FGF21 expression and release in brown adipose tissue', Journal of Biological Chemistry, 286: 12983-90.

Hui, X., P. Gu, J. Zhang, T. Nie, Y. Pan, D. Wu, T. Feng, C. Zhong, Y. Wang, K. S. Lam, and A. Xu. 2015. 'Adiponectin Enhances Cold-Induced Browning of Subcutaneous Adipose Tissue via Promoting M2 Macrophage Proliferation', Cell Metab, 22: 279-90.

Kang, Y. E., S. Choung, J. H. Lee, H. J. Kim, and B. J. Ku. 2017. 'The Role of Circulating Slit2, the One of the Newly Batokines, in Human Diabetes Mellitus', Endocrinol Metab (Seoul), 32: 383-88.

Kawai, M., A. C. Breggia, V. E. DeMambro, X. Shen, E. Canalis, M. L. Bouxsein, W. G. Beamer, D. R. Clemmons, and C. J. Rosen. 2011. 'The heparin-binding domain of IGFBP-2 has insulin-like growth factor binding-independent biologic activity in the growing skeleton', J Biol Chem, 286: 14670-80.

Khayat, M. T., and M. A. Nayeem. 2017. 'The Role of Adenosine A2A Receptor, CYP450s, and PPARs in the Regulation of Vascular Tone', Biomed Res Int, 2017: 1720920.

Kiefer, F. W. 2017. 'The significance of beige and brown fat in humans', Endocr Connect, 6: R70-R79.

Kim, W. K., H. R. Choi, S. G. Park, Y. Ko, K. H. Bae, and S. C. Lee. 2012. 'Myostatin inhibits brown adipocyte differentiation via regulation of Smad3-mediated beta-catenin stabilization', Int $J$ Biochem Cell Biol, 44: 327-34.

Klepac, K., A. Kilic, T. Gnad, L. M. Brown, B. Herrmann, A. Wilderman, A. Balkow, A. Glode, K. Simon, M. E. Lidell, M. J. Betz, S. Enerback, J. Wess, M. Freichel, M. Bluher, G. Konig, E. Kostenis, P. A. Insel, and A. Pfeifer. 2016. 'The Gq signalling pathway inhibits brown and beige adipose tissue', Nat Commun, 7: 10895.

Kong, X., T. Yao, P. Zhou, L. Kazak, D. Tenen, A. Lyubetskaya, B. A. Dawes, L. Tsai, B. B. Kahn, B. M. Spiegelman, T. Liu, and E. D. Rosen. 2018. 'Brown Adipose Tissue Controls Skeletal Muscle Function via the Secretion of Myostatin', Cell Metab, 28: 631-43 e3.

Kristof, E., A. Klusoczki, R. Veress, A. Shaw, Z. S. Combi, K. Varga, F. Gyory, Z. Balajthy, P. Bai, Z. Bacso, and L. Fesus. 2019. 'Interleukin- 6 released from differentiating human beige adipocytes improves browning', Exp Cell Res, 377: 47-55.

Lafontan, M., and M. Berlan. 1993. 'Fat cell adrenergic receptors and the control of white and brown fat cell function', J Lipid Res, 34: 1057-91.

Ledent, C., J. M. Vaugeois, S. N. Schiffmann, T. Pedrazzini, M. El Yacoubi, J. J. Vanderhaeghen, J. Costentin, J. K. Heath, G. Vassart, and M. Parmentier. 1997. 'Aggressiveness, hypoalgesia and high blood pressure in mice lacking the adenosine A2a receptor', Nature, 388: 674-8.

Lee, M. W., M. Lee, and K. J. Oh. 2019. 'Adipose Tissue-Derived Signatures for Obesity and Type 2 Diabetes: Adipokines, Batokines and MicroRNAs', J Clin Med, 8.

Lee, P., S. Smith, J. Linderman, A. B. Courville, R. J. Brychta, W. Dieckmann, C. D. Werner, K. Y. Chen, and F. S. Celi. 2014. 'Temperature-acclimated brown adipose tissue modulates insulin sensitivity in humans', Diabetes, 63: 3686-98.

Lehnig, A. C., R. S. Dewal, L. A. Baer, K. M. Kitching, V. R. Munoz, P. J. Arts, D. A. Sindeldecker, F. J. May, Hpmm Lauritzen, L. J. Goodyear, and K. I. Stanford. 2019. 'Exercise Training Induces DepotSpecific Adaptations to White and Brown Adipose Tissue', iScience, 11: 425-39.

Leiria, L. O., C. H. Wang, M. D. Lynes, K. Yang, F. Shamsi, M. Sato, S. Sugimoto, E. Y. Chen, V. Bussberg, N. R. Narain, B. E. Sansbury, J. Darcy, T. L. Huang, S. D. Kodani, M. Sakaguchi, A. L. Rocha, T. J. Schulz, A. Bartelt, G. S. Hotamisligil, M. F. Hirshman, K. van Leyen, L. J. Goodyear, M. Blüher, A. M. Cypess, M. A. Kiebish, M. Spite, and Y. H. Tseng. 2019. '12-Lipoxygenase Regulates Cold Adaptation and Glucose Metabolism by Producing the Omega-3 Lipid 12-HEPE from Brown Fat', Cell Metab, 30: 768-83.e7. 
Molecular Pharmacology Fast Forward. Published on December 21, 2021 as DOI: 10.1124/molpharm.121.000328

This article has not been copyedited and formatted. The final version may differ from this version.

\section{Heartwarming Effect of BAT}

Liu, S. Q., D. Roberts, A. Kharitonenkov, B. Zhang, S. M. Hanson, Y. C. Li, L. Q. Zhang, and Y. H. Wu. 2013. 'Endocrine protection of ischemic myocardium by FGF21 from the liver and adipose tissue', Sci Rep, 3: 2767.

Liu, X., S. Wang, Y. You, M. Meng, Z. Zheng, M. Dong, J. Lin, Q. Zhao, C. Zhang, X. Yuan, T. Hu, L. Liu, Y. Huang, L. Zhang, D. Wang, J. Zhan, H. Jong Lee, J. R. Speakman, and W. Jin. 2015. 'Brown Adipose Tissue Transplantation Reverses Obesity in Ob/Ob Mice', Endocrinology, 156: 2461-9.

Lynes, M. D., L. O. Leiria, M. Lundh, A. Bartelt, F. Shamsi, T. L. Huang, H. Takahashi, M. F. Hirshman, C. Schlein, A. Lee, L. A. Baer, F. J. May, F. Gao, N. R. Narain, E. Y. Chen, M. A. Kiebish, A. M. Cypess, M. Bluher, L. J. Goodyear, G. S. Hotamisligil, K. I. Stanford, and Y. H. Tseng. 2017. 'The cold-induced lipokine 12,13-diHOME promotes fatty acid transport into brown adipose tissue', Nat Med, 23: 631-37. Ma, Y., M. Gao, H. Sun, and D. Liu. 2015. 'Interleukin-6 gene transfer reverses body weight gain and fatty liver in obese mice', Biochim Biophys Acta, 1852: 1001-11.

Mancia, G., and G. Grassi. 2014. 'The autonomic nervous system and hypertension', Circ Res, 114: 1804-14.

Mauer, J., B. Chaurasia, J. Goldau, M. C. Vogt, J. Ruud, K. D. Nguyen, S. Theurich, A. C. Hausen, J. Schmitz, H. S. Bronneke, E. Estevez, T. L. Allen, A. Mesaros, L. Partridge, M. A. Febbraio, A. Chawla, F. T. Wunderlich, and J. C. Bruning. 2014. 'Signaling by IL-6 promotes alternative activation of macrophages to limit endotoxemia and obesity-associated resistance to insulin', Nat Immunol, 15: 423-30.

Messerli, F. H., S. F. Rimoldi, and S. Bangalore. 2017. 'The Transition From Hypertension to Heart Failure: Contemporary Update', JACC Heart Fail, 5: 543-51.

Mirbolooki, M. R., C. C. Constantinescu, M. L. Pan, and J. Mukherjee. 2013. 'Targeting presynaptic norepinephrine transporter in brown adipose tissue: a novel imaging approach and potential treatment for diabetes and obesity', Synapse, 67: 79-93.

Moore, J. X., N. Chaudhary, and T. Akinyemiju. 2017. 'Metabolic Syndrome Prevalence by Race/Ethnicity and Sex in the United States, National Health and Nutrition Examination Survey, 1988-2012', Prev Chronic Dis, 14: E24.

Mukherjee, J., A. Baranwal, and K. N. Schade. 2016. 'Classification of Therapeutic and Experimental Drugs for Brown Adipose Tissue Activation: Potential Treatment Strategies for Diabetes and Obesity', Curr Diabetes Rev, 12: 414-28.

Murphy, E., and C. Steenbergen. 2008. 'Mechanisms underlying acute protection from cardiac ischemiareperfusion injury', Physiol Rev, 88: 581-609.

Nayor, M., R. V. Shah, P. E. Miller, J. B. Blodgett, M. Tanguay, A. R. Pico, V. L. Murthy, R. Malhotra, N. E. Houstis, A. Deik, K. A. Pierce, K. Bullock, L. Dailey, R. S. Velagaleti, S. A. Moore, J. E. Ho, A. L. Baggish, C. B. Clish, M. G. Larson, R. S. Vasan, and G. D. Lewis. 2020. 'Metabolic Architecture of Acute Exercise Response in Middle-Aged Adults in the Community', Circulation, 142: 1905-24.

Nechad, M., E. Ruka, and J. Thibault. 1994. 'Production of nerve growth factor by brown fat in culture: relation with the in vivo developmental stage of the tissue', Comp Biochem Physiol Comp Physiol, 107: 381-8.

Nedergaard, J., T. Bengtsson, and B. Cannon. 2007. 'Unexpected evidence for active brown adipose tissue in adult humans', Am J Physiol Endocrinol Metab, 293: E444-52.

O'Mara, A. E., J. W. Johnson, J. D. Linderman, R. J. Brychta, S. McGehee, L. A. Fletcher, Y. A. Fink, D. Kapuria, T. M. Cassimatis, N. Kelsey, C. Cero, Z. A. Sater, F. Piccinini, A. S. Baskin, B. P. Leitner, H. Cai, C. M. Millo, W. Dieckmann, M. Walter, N. B. Javitt, Y. Rotman, P. J. Walter, M. Ader, R. N. Bergman, P. Herscovitch, K. Y. Chen, and A. M. Cypess. 2020. 'Chronic mirabegron treatment increases human brown fat, HDL cholesterol, and insulin sensitivity', J Clin Invest, 130: 2209-19.

Organization, World Health. 2018. 'Global Health Estimates 2016: Deaths by Cause, Age, Sex, by Country and by Region, 2000- 2016.'. http://www.who.int/healthinfo/global burden disease/estimates/en/. Ouellet, V., A. Routhier-Labadie, W. Bellemare, L. Lakhal-Chaieb, E. Turcotte, A. C. Carpentier, and D. Richard. 2011. 'Outdoor temperature, age, sex, body mass index, and diabetic status determine the prevalence, mass, and glucose-uptake activity of 18F-FDG-detected BAT in humans', J Clin Endocrinol Metab, 96: 192-9.

Pagnon, J., M. Matzaris, R. Stark, R. C. Meex, S. L. Macaulay, W. Brown, P. E. O'Brien, T. Tiganis, and M. J. Watt. 2012. 'Identification and functional characterization of protein kinase A phosphorylation sites in the major lipolytic protein, adipose triglyceride lipase', Endocrinology, 153: 4278-89.

Peirce, V., and A. Vidal-Puig. 2013. 'Regulation of glucose homoeostasis by brown adipose tissue', Lancet Diabetes Endocrinol, 1: 353-60. 
Molecular Pharmacology Fast Forward. Published on December 21, 2021 as DOI: 10.1124/molpharm.121.000328

This article has not been copyedited and formatted. The final version may differ from this version.

\section{Heartwarming Effect of BAT}

Pellegrinelli, V., V. J. Peirce, L. Howard, S. Virtue, D. Turei, M. Senzacqua, A. Frontini, J. W. Dalley, A. R. Horton, G. Bidault, I. Severi, A. Whittle, K. Rahmouni, J. Saez-Rodriguez, S. Cinti, A. M. Davies, and A. Vidal-Puig. 2018. 'Adipocyte-secreted BMP8b mediates adrenergic-induced remodeling of the neurovascular network in adipose tissue', Nat Commun, 9: 4974.

Peres Valgas da Silva, C., D. Hernandez-Saavedra, J. D. White, and K. I. Stanford. 2019. 'Cold and Exercise: Therapeutic Tools to Activate Brown Adipose Tissue and Combat Obesity', Biology (Basel), 8. Pinckard, K. M., V. K. Shettigar, K. R. Wright, E. Abay, L. A. Baer, P. Vidal, R. S. Dewal, D. Das, S. Duarte-Sanmiguel, D. Hernandez-Saavedra, P. J. Arts, A. C. Lehnig, V. Bussberg, N. R. Narain, M. A. Kiebish, F. Yi, L. M. Sparks, B. H. Goodpaster, S. R. Smith, R. E. Pratley, E. D. Lewandowski, S. V. Raman, L. E. Wold, D. Gallego-Perez, P. M. Coen, M. T. Ziolo, and K. I. Stanford. 2021. 'A Novel Endocrine Role for the BAT-Released Lipokine 12,13-diHOME to Mediate Cardiac Function', Circulation, 143: 145-59.

Planavila, A., I. Redondo, E. Hondares, M. Vinciguerra, C. Munts, R. Iglesias, L. A. Gabrielli, M. Sitges, M. Giralt, M. van Bilsen, and F. Villarroya. 2013. 'Fibroblast growth factor 21 protects against cardiac hypertrophy in mice', Nat Commun, 4: 2019.

Prabhu, S. D. 2004. 'Cytokine-induced modulation of cardiac function', Circ Res, 95: 1140-53.

Prabhu, S. D., and N. G. Frangogiannis. 2016. 'The Biological Basis for Cardiac Repair After Myocardial Infarction: From Inflammation to Fibrosis', Circ Res, 119: 91-112.

Prevention, Division for Heart Dlsease and Stroke. 2017. 'Heart Disease Fact Sheet', Accessed 1/19. Prevention., Centers for Disease Control and. 2018. "Underlying Cause of Death, 1999-2018. ." In CDC WONDER Online Database. , edited by Centers for DIsease Control and Prevention. Atlanta, GA. . Rahman, S., Y. Lu, P. J. Czernik, C. J. Rosen, S. Enerback, and B. Lecka-Czernik. 2013. 'Inducible brown adipose tissue, or beige fat, is anabolic for the skeleton', Endocrinology, 154: 2687-701.

Raiko, J., J. Orava, N. Savisto, and K. A. Virtanen. 2020. 'High Brown Fat Activity Correlates With Cardiovascular Risk Factor Levels Cross-Sectionally and Subclinical Atherosclerosis at 5-Year FollowUp', Arterioscler Thromb Vasc Biol, 40: 1289-95.

Rao, R. R., J. Z. Long, J. P. White, K. J. Svensson, J. Lou, I. Lokurkar, M. P. Jedrychowski, J. L. Ruas, C. D. Wrann, J. C. Lo, D. M. Camera, J. Lachey, S. Gygi, J. Seehra, J. A. Hawley, and B. M. Spiegelman. 2014. 'Meteorin-like is a hormone that regulates immune-adipose interactions to increase beige fat thermogenesis', Cell, 157: 1279-91.

Riis-Vestergaard, M. J., B. Richelsen, J. M. Bruun, W. Li, J. B. Hansen, and S. B. Pedersen. 2020. 'Beta1 and Not Beta-3 Adrenergic Receptors May Be the Primary Regulator of Human Brown Adipocyte Metabolism', J Clin Endocrinol Metab, 105.

Rocha, V. Z., and P. Libby. 2009. 'Obesity, inflammation, and atherosclerosis', Nat Rev Cardiol, 6: 399409.

Rohlfs, E. M., K. W. Daniel, R. T. Premont, L. P. Kozak, and S. Collins. 1995. 'Regulation of the uncoupling protein gene (Ucp) by beta 1 , beta 2 , and beta 3 -adrenergic receptor subtypes in immortalized brown adipose cell lines', Journal of Biological Chemistry, 270: 10723-32.

Rosell, M., M. Kaforou, A. Frontini, A. Okolo, Y. W. Chan, E. Nikolopoulou, S. Millership, M. E. Fenech, D. MacIntyre, J. O. Turner, J. D. Moore, E. Blackburn, W. J. Gullick, S. Cinti, G. Montana, M. G. Parker, and M. Christian. 2014. 'Brown and white adipose tissues: intrinsic differences in gene expression and response to cold exposure in mice', Am J Physiol Endocrinol Metab, 306: E945-64.

Ruan, C. C., L. R. Kong, X. H. Chen, Y. Ma, X. X. Pan, Z. B. Zhang, and P. J. Gao. 2018. 'A2A Receptor Activation Attenuates Hypertensive Cardiac Remodeling via Promoting Brown Adipose Tissue-Derived FGF21', Cell Metab, 28: 476-89 e5.

Saito, M., Y. Okamatsu-Ogura, M. Matsushita, K. Watanabe, T. Yoneshiro, J. Nio-Kobayashi, T. Iwanaga, M. Miyagawa, T. Kameya, K. Nakada, Y. Kawai, and M. Tsujisaki. 2009. 'High incidence of metabolically active brown adipose tissue in healthy adult humans: effects of cold exposure and adiposity', Diabetes, 58: 1526-31.

Silva, J. E., and P. R. Larsen. 1985. 'Potential of brown adipose tissue type II thyroxine 5'-deiodinase as a local and systemic source of triiodothyronine in rats', J Clin Invest, 76: 2296-305.

Singh, R., M. Braga, and S. Pervin. 2014. 'Regulation of brown adipocyte metabolism by myostatin/follistatin signaling', Front Cell Dev Biol, 2: 60.

Stanford, K. I., M. D. Lynes, H. Takahashi, L. A. Baer, P. J. Arts, F. J. May, A. C. Lehnig, R. J. W. Middelbeek, J. J. Richard, K. So, E. Y. Chen, F. Gao, N. R. Narain, G. Distefano, V. K. Shettigar, M. F. Hirshman, M. T. Ziolo, M. A. Kiebish, Y. H. Tseng, P. M. Coen, and L. J. Goodyear. 2018. '12,13- 
Molecular Pharmacology Fast Forward. Published on December 21, 2021 as DOI: 10.1124/molpharm.121.000328

This article has not been copyedited and formatted. The final version may differ from this version.

\section{Heartwarming Effect of BAT}

diHOME: An Exercise-Induced Lipokine that Increases Skeletal Muscle Fatty Acid Uptake', Cell Metab, 27: 1111-20 e3.

Stanford, K. I., R. J. Middelbeek, K. L. Townsend, D. An, E. B. Nygaard, K. M. Hitchcox, K. R. Markan, K. Nakano, M. F. Hirshman, Y. H. Tseng, and L. J. Goodyear. 2013. 'Brown adipose tissue regulates glucose homeostasis and insulin sensitivity', J Clin Invest, 123: 215-23.

Steculorum, S. M., J. Ruud, I. Karakasilioti, H. Backes, L. Engstrom Ruud, K. Timper, M. E. Hess, E. Tsaousidou, J. Mauer, M. C. Vogt, L. Paeger, S. Bremser, A. C. Klein, D. A. Morgan, P. Frommolt, P. T. Brinkkotter, P. Hammerschmidt, T. Benzing, K. Rahmouni, F. T. Wunderlich, P. Kloppenburg, and J. C. Bruning. 2016. 'AgRP Neurons Control Systemic Insulin Sensitivity via Myostatin Expression in Brown Adipose Tissue', Cell, 165: 125-38.

Svensson, K. J., J. Z. Long, M. P. Jedrychowski, P. Cohen, J. C. Lo, S. Serag, S. Kir, K. Shinoda, J. A. Tartaglia, R. R. Rao, A. Chedotal, S. Kajimura, S. P. Gygi, and B. M. Spiegelman. 2016. 'A Secreted Slit2 Fragment Regulates Adipose Tissue Thermogenesis and Metabolic Function', Cell Metab, 23: 454-66. Takx, R. A., A. Ishai, Q. A. Truong, M. H. MacNabb, M. Scherrer-Crosbie, and A. Tawakol. 2016. 'Supraclavicular Brown Adipose Tissue 18F-FDG Uptake and Cardiovascular Disease', J Nucl Med, 57: 1221-5.

Terrell, A. M., P. R. Crisostomo, G. M. Wairiuko, M. Wang, E. D. Morrell, and D. R. Meldrum. 2006. 'Jak/STAT/SOCS signaling circuits and associated cytokine-mediated inflammation and hypertrophy in the heart', Shock, 26: 226-34.

Thoonen, R., L. Ernande, J. Cheng, Y. Nagasaka, V. Yao, A. Miranda-Bezerra, C. Chen, W. Chao, M. Panagia, D. E. Sosnovik, D. Puppala, A. A. Armoundas, A. Hindle, K. D. Bloch, E. S. Buys, and M. Scherrer-Crosbie. 2015. 'Functional brown adipose tissue limits cardiomyocyte injury and adverse remodeling in catecholamine-induced cardiomyopathy', J Mol Cell Cardiol, 84: 202-11.

Thoonen, R., A. G. Hindle, and M. Scherrer-Crosbie. 2016. 'Brown adipose tissue: The heat is on the heart', Am J Physiol Heart Circ Physiol, 310: H1592-605.

Tian, X. Y., K. Ganeshan, C. Hong, K. D. Nguyen, Y. Qiu, J. Kim, R. K. Tangirala, P. Tontonoz, and A. Chawla. 2016. 'Thermoneutral Housing Accelerates Metabolic Inflammation to Potentiate Atherosclerosis but Not Insulin Resistance', Cell Metab, 23: 165-78.

van Berlo, J. H., M. Maillet, and J. D. Molkentin. 2013. 'Signaling effectors underlying pathologic growth and remodeling of the heart', J Clin Invest, 123: 37-45.

van der Lans, A. A., J. Hoeks, B. Brans, G. H. Vijgen, M. G. Visser, M. J. Vosselman, J. Hansen, J. A. Jorgensen, J. Wu, F. M. Mottaghy, P. Schrauwen, and W. D. van Marken Lichtenbelt. 2013. 'Cold acclimation recruits human brown fat and increases nonshivering thermogenesis', J Clin Invest, 123: 3395-403.

Van Gaal, L. F., I. L. Mertens, and C. E. De Block. 2006. 'Mechanisms linking obesity with cardiovascular disease', Nature, 444: 875-80.

van Marken Lichtenbelt, W. D., and P. Schrauwen. 2011. 'Implications of nonshivering thermogenesis for energy balance regulation in humans', Am J Physiol Regul Integr Comp Physiol, 301: R285-96.

van Marken Lichtenbelt, W. D., J. W. Vanhommerig, N. M. Smulders, J. M. Drossaerts, G. J. Kemerink, N. D. Bouvy, P. Schrauwen, and G. J. Teule. 2009. 'Cold-activated brown adipose tissue in healthy men', $N$ Engl J Med, 360: 1500-8.

Vasan, S. K., R. Noordam, M. S. Gowri, M. J. Neville, F. Karpe, and C. Christodoulides. 2019. 'The proposed systemic thermogenic metabolites succinate and 12,13-diHOME are inversely associated with adiposity and related metabolic traits: evidence from a large human cross-sectional study', Diabetologia, 62: 2079-87.

Vijgen, G. H., N. D. Bouvy, G. J. Teule, B. Brans, P. Schrauwen, and W. D. van Marken Lichtenbelt. 2011. 'Brown adipose tissue in morbidly obese subjects', PLoS One, 6: e17247.

Villarroya, F., R. Cereijo, J. Villarroya, and M. Giralt. 2017. 'Brown adipose tissue as a secretory organ', Nat Rev Endocrinol, 13: 26-35.

Villarroya, F., A. Gavalda-Navarro, M. Peyrou, J. Villarroya, and M. Giralt. 2017. 'The Lives and Times of Brown Adipokines', Trends Endocrinol Metab, 28: 855-67.

Villarroya, J., R. Cereijo, A. Gavalda-Navarro, M. Peyrou, M. Giralt, and F. Villarroya. 2019. 'New insights into the secretory functions of brown adipose tissue', J Endocrinol, 243: R19-R27.

Virtanen, K. A., M. E. Lidell, J. Orava, M. Heglind, R. Westergren, T. Niemi, M. Taittonen, J. Laine, N. J. Savisto, S. Enerback, and P. Nuutila. 2009. 'Functional brown adipose tissue in healthy adults', $N$ Engl J Med, 360: 1518-25. 


\section{Heartwarming Effect of BAT}

Wang, G. X., X. Y. Zhao, and J. D. Lin. 2015. 'The brown fat secretome: metabolic functions beyond thermogenesis', Trends Endocrinol Metab, 26: 231-7.

Wang, G. X., X. Y. Zhao, Z. X. Meng, M. Kern, A. Dietrich, Z. Chen, Z. Cozacov, D. Zhou, A. L. Okunade, X. Su, S. Li, M. Bluher, and J. D. Lin. 2014. 'The brown fat-enriched secreted factor Nrg4 preserves metabolic homeostasis through attenuation of hepatic lipogenesis', Nat Med, 20: 1436-43.

Wang, Q. A., C. Tao, L. Jiang, M. Shao, R. Ye, Y. Zhu, R. Gordillo, A. Ali, Y. Lian, W. L. Holland, R. K. Gupta, and P. E. Scherer. 2015. 'Distinct regulatory mechanisms governing embryonic versus adult adipocyte maturation', Nat Cell Biol, 17: 1099-111.

Wang, Q., M. Zhang, M. Xu, W. Gu, Y. Xi, L. Qi, B. Li, and W. Wang. 2015. 'Brown adipose tissue activation is inversely related to central obesity and metabolic parameters in adult human', PLoS One, 10: e0123795.

Wang, Z. H., Y. F. Li, and Y. Q. Guo. 2013. 'beta3-Adrenoceptor activation attenuates atherosclerotic plaque formation in ApoE(-/-) mice through lowering blood lipids and glucose', Acta Pharmacol Sin, 34: 1156-63.

Wei, G., H. Sun, J. L. Liu, K. Dong, J. Liu, and M. Zhang. 2020. 'Indirubin, a small molecular deriving from connectivity map (CMAP) screening, ameliorates obesity-induced metabolic dysfunction by enhancing brown adipose thermogenesis and white adipose browning', Nutr Metab (Lond), 17: 21.

Wernicke, J. F., and C. J. Kratochvil. 2002. 'Safety profile of atomoxetine in the treatment of children and adolescents with ADHD', J Clin Psychiatry, 63 Suppl 12: 50-5.

White, J. D., R. S. Dewal, and K. I. Stanford. 2019. 'The beneficial effects of brown adipose tissue transplantation', Mol Aspects Med, 68: 74-81.

Whittle, A. J., S. Carobbio, L. Martins, M. Slawik, E. Hondares, M. J. Vazquez, D. Morgan, R. I. Csikasz, R. Gallego, S. Rodriguez-Cuenca, M. Dale, S. Virtue, F. Villarroya, B. Cannon, K. Rahmouni, M. Lopez, and A. Vidal-Puig. 2012. 'BMP8B increases brown adipose tissue thermogenesis through both central and peripheral actions', Cell, 149: 871-85.

Wollert, K. C., T. Taga, M. Saito, M. Narazaki, T. Kishimoto, C. C. Glembotski, A. B. Vernallis, J. K. Heath, D. Pennica, W. I. Wood, and K. R. Chien. 1996. 'Cardiotrophin-1 activates a distinct form of cardiac muscle cell hypertrophy. Assembly of sarcomeric units in series VIA gp130/leukemia inhibitory factor receptor-dependent pathways', J Biol Chem, 271: 9535-45.

Wu, J., P. Bostrom, L. M. Sparks, L. Ye, J. H. Choi, A. H. Giang, M. Khandekar, K. A. Virtanen, P. Nuutila, G. Schaart, K. Huang, H. Tu, W. D. van Marken Lichtenbelt, J. Hoeks, S. Enerback, P. Schrauwen, and B. M. Spiegelman. 2012. 'Beige adipocytes are a distinct type of thermogenic fat cell in mouse and human', Cell, 150: 366-76.

Yamauchi-Takihara, K., Y. Ihara, A. Ogata, K. Yoshizaki, J. Azuma, and T. Kishimoto. 1995. 'Hypoxic stress induces cardiac myocyte-derived interleukin-6', Circulation, 91: 1520-4.

Yoneshiro, T., S. Aita, M. Matsushita, T. Kayahara, T. Kameya, Y. Kawai, T. Iwanaga, and M. Saito. 2013. 'Recruited brown adipose tissue as an antiobesity agent in humans', J Clin Invest, 123: 3404-8.

Zeng, X., M. Ye, J. M. Resch, M. P. Jedrychowski, B. Hu, B. B. Lowell, D. D. Ginty, and B. M. Spiegelman. 2019. 'Innervation of thermogenic adipose tissue via a calsyntenin 3beta-S100b axis', Nature, 569: 229-35.

Zhang, D. Y., and A. S. Anderson. 2014. 'The sympathetic nervous system and heart failure', Cardiol Clin, 32: 33-45, vii.

Zhao, J., L. Unelius, T. Bengtsson, B. Cannon, and J. Nedergaard. 1994. 'Coexisting beta-adrenoceptor subtypes: significance for thermogenic process in brown fat cells', Am J Physiol, 267: C969-79.

Zoico, E., S. Rubele, A. De Caro, N. Nori, G. Mazzali, F. Fantin, A. Rossi, and M. Zamboni. 2019. 'Brown and Beige Adipose Tissue and Aging', Front Endocrinol (Lausanne), 10: 368.

Table 1. Batokines and their known functions.

\begin{tabular}{|l|l|l|l|l|l|}
\hline Batokine & Class & $\begin{array}{l}\text { Endogenous } \\
\text { tissue(s) }\end{array}$ & $\begin{array}{l}\text { Confirmed } \\
\text { stimulation }\end{array}$ & Function(s) & References \\
\hline Adenosine & Nucleoside & - & $\begin{array}{l}\text { B-adrenergic } \\
\text { stimulation }\end{array}$ & $\begin{array}{l}\text { Activates } \\
\text { thermogenesis in } \\
\text { BAT; induces } \\
\text { beiging in WAT; } \\
\text { reduces obesity in } \\
\text { mice }\end{array}$ & $\begin{array}{l}\text { (Lee, Lee, } \\
\text { and Oh 2019; } \\
\text { Gnad et al. } \\
2014)\end{array}$ \\
& & & & & \\
\hline
\end{tabular}


Molecular Pharmacology Fast Forward. Published on December 21, 2021 as DOI: 10.1124/molpharm.121.000328

This article has not been copyedited and formatted. The final version may differ from this version.

Heartwarming Effect of BAT

\begin{tabular}{|c|c|c|c|c|c|}
\hline Adiponectin & $\begin{array}{l}\text { Protein } \\
\text { hormone }\end{array}$ & BAT, WAT & Cold exposure & $\begin{array}{l}\text { Promotes WAT } \\
\text { beiging }\end{array}$ & $\begin{array}{l}\text { (Ahmad et al. } \\
\text { 2021; Hui et } \\
\text { al. 2015) }\end{array}$ \\
\hline $\begin{array}{l}\text { Angiopoietin- } \\
\text { Like8 } \\
\text { (ANGPTL8) } \\
\text { Or Lipasin }\end{array}$ & Protein & $\begin{array}{l}\text { BAT, WAT, } \\
\text { liver }\end{array}$ & Cold exposure & $\begin{array}{l}\text { Not fully } \\
\text { elucidated, but } \\
\text { assumed to } \\
\text { negatively } \\
\text { regulate BAT } \\
\text { thermogenesis }\end{array}$ & $\begin{array}{l}\text { (Lee, Lee, } \\
\text { and Oh 2019; } \\
\text { Fu et al. } \\
\text { 2013) }\end{array}$ \\
\hline BMP8-b & Protein & $\begin{array}{l}\text { BAT, } \\
\text { hypothalamus }\end{array}$ & - & $\begin{array}{l}\text { Regulates } \\
\text { thermogenesis, } \\
\text { promotes } \\
\text { sympathetic } \\
\text { innervation of } \\
\text { adipose tissue via } \\
\text { NRG-4, enhances } \\
\text { lipolysis via HSL }\end{array}$ & $\begin{array}{l}\text { (Ahmad et al. } \\
2021 ; \\
\text { Pellegrinelli } \\
\text { et al. 2018; } \\
\text { Whittle et al. } \\
\text { 2012) }\end{array}$ \\
\hline CXCL14 & Cytokine & BAT & Cold exposure & $\begin{array}{l}\text { Promotes WAT } \\
\text { beiging, } \\
\text { alternatively } \\
\text { activated M2 } \\
\text { macrophage } \\
\text { recruitment }\end{array}$ & $\begin{array}{l}\text { (Ahmad et al. } \\
\text { 2021; Cereijo } \\
\text { et al. 2018) }\end{array}$ \\
\hline Endothelin 1 & $\begin{array}{l}\text { 21-amino } \\
\text { acid } \\
\text { peptide }\end{array}$ & $\begin{array}{l}\text { BAT, beige } \\
\text { adipocytes, } \\
\text { vascular } \\
\text { endothelial } \\
\text { cells, brain }\end{array}$ & $\begin{array}{l}\mathrm{G}_{\mathrm{q}} \text { signlaing, } \\
\text { inhibited by } \beta \text { - } \\
\text { adrenergic } \\
\text { stimulation }\end{array}$ & $\begin{array}{l}\text { Suppresses UCP1 } \\
\text { expression, beige } \\
\text { and brown } \\
\text { adipogenesis and } \\
\text { whole-body } \\
\text { energy } \\
\text { expenditure }\end{array}$ & $\begin{array}{l}\text { (Ahmad et al. } \\
\text { 2021; Klepac } \\
\text { et al. 2016; } \\
\text { Lee, Lee, } \\
\text { and Oh } \\
\text { 2019) }\end{array}$ \\
\hline EPDR1 & Protein & BAT, WAT & - & $\begin{array}{l}\text { Thermogenic } \\
\text { (beige/brown) } \\
\text { adipocyte } \\
\text { differentiation; } \beta \text { - } \\
\text { adrenergic signal } \\
\text { response, } \\
\text { important in BAT } \\
\text { mitochondrial } \\
\text { respiration and } \\
\text { whole body } \\
\text { metabolism }\end{array}$ & $\begin{array}{l}\text { (Ahmad et al. } \\
2021 \text {; } \\
\text { Deshmukh et } \\
\text { al. 2019) }\end{array}$ \\
\hline FGF21 & Protein & $\begin{array}{l}\text { BAT, liver, } \\
\text { skeletal } \\
\text { muscle, heart }\end{array}$ & $\begin{array}{l}\text { Cold exposure, } \\
\beta \text {-adrenergic } \\
\text { stimulation, BAT } \\
\text { Tx }\end{array}$ & $\begin{array}{l}\text { Protection against } \\
\text { hypertension, } \\
\text { cardiac } \\
\text { hypertrophy and } \\
\text { MI injury. } \\
\text { Promotes WAT } \\
\text { beiging, increases } \\
\text { thermogenic } \\
\text { function in BAT, } \\
\text { and reduces } \\
\text { dyslipidemia and } \\
\text { insulin resistance } \\
\text { in T2D patients }\end{array}$ & $\begin{array}{l}\text { (Ahmad et al. } \\
\text { 2021; } \\
\text { Stanford et } \\
\text { al. 2013; Lee } \\
\text { et al. 2014; } \\
\text { Ruan et al. } \\
\text { 2018; } \\
\text { Planavila et } \\
\text { al. 2013; Liu } \\
\text { et al. 2013; } \\
\text { Hondares et } \\
\text { al. 2011; } \\
\text { Wang, Tao, } \\
\text { et al. 2015; } \\
\text { Gaich et al. } \\
\end{array}$ \\
\hline
\end{tabular}


Molecular Pharmacology Fast Forward. Published on December 21, 2021 as DOI: 10.1124/molpharm.121.000328

This article has not been copyedited and formatted. The final version may differ from this version.

Heartwarming Effect of BAT

\begin{tabular}{|c|c|c|c|c|c|}
\hline & & & & & $\begin{array}{l}2013 ; \\
\text { Villarroya, } \\
\text { Gavalda- } \\
\text { Navarro, et } \\
\text { al. 2017) } \\
\end{array}$ \\
\hline Follistatin (Fst) & $\begin{array}{l}\text { Glycoprotei } \\
n\end{array}$ & $\begin{array}{l}\text { BAT, nearly } \\
\text { all tissues }\end{array}$ & Cold exposure & $\begin{array}{l}\text { Inhibits TGF- } \\
\beta / \text { Smad3/myostati } \\
n \text { signaling and } \\
\text { therefore } \\
\text { promotes BAT } \\
\text { function, and } \\
\text { improves lipid } \\
\text { homeostasis and } \\
\text { whole body } \\
\text { metabolism. }\end{array}$ & $\begin{array}{l}\text { (Lee, Lee, } \\
\text { and Oh 2019; } \\
\text { Singh, Braga, } \\
\text { and Pervin } \\
\text { 2014) }\end{array}$ \\
\hline GDF-15 & Cytokine & $\begin{array}{l}\text { BAT, liver, } \\
\text { kidney, heart } \\
\text { and lung }\end{array}$ & $\begin{array}{l}\text { Cold exposure, } \\
\beta \text {-adrenergic } \\
\text { (requires } \\
\text { FGF21) }\end{array}$ & $\begin{array}{l}\text { Targets } \\
\text { macrophages; } \\
\text { anti-inflammatory }\end{array}$ & $\begin{array}{l}\text { (Ahmad et al. } \\
2021 ; \\
\text { Campderros } \\
\text { et al. 2019) }\end{array}$ \\
\hline IL-6 & Interleukin & $\begin{array}{l}\text { BAT, heart, } \\
\text { smooth } \\
\text { muscle, } \\
\text { skeletal } \\
\text { muscle }\end{array}$ & $\begin{array}{l}\text { BAT Tx, } \beta \text { - } \\
\text { adrenergic }\end{array}$ & $\begin{array}{l}\text { Promotes glucose } \\
\text { uptake into BAT, } \\
\text { WAT \& heart; } \\
\text { promotes } \\
\text { adipocyte } \\
\text { browning; } \\
\text { cardioprotection } \\
\text { against MI injury; } \\
\text { promotes } \\
\text { alternative M2 } \\
\text { macrophage } \\
\text { activation }\end{array}$ & $\begin{array}{l}\text { (Ahmad et al. } \\
2021 ; \\
\text { Stanford et } \\
\text { al. 2013; } \\
\text { Kristof et al. } \\
2019 ; \\
\text { Burysek and } \\
\text { Houstek } \\
1997 ; \\
\text { Villarroya, } \\
\text { Gavalda- } \\
\text { Navarro, et } \\
\text { al. 2017; } \\
\text { Mauer et al. } \\
\text { 2014) }\end{array}$ \\
\hline IGF1 & $\begin{array}{l}\text { Protein } \\
\text { hormone }\end{array}$ & BAT, liver & $\begin{array}{l}\text { Cold exposure, } \\
\text { BAT Tx }\end{array}$ & $\begin{array}{l}\text { Promotes } \beta \text {-cell } \\
\text { function, protects } \\
\text { against } \\
\text { cytotoxicity and } \\
\text { insulitis, anti- } \\
\text { inflammatory; anti- } \\
\text { diabetic }\end{array}$ & $\begin{array}{l}\text { (Ahmad et al. } \\
\text { 2021; } \\
\text { Gunawardan } \\
\text { a and Piston } \\
\text { 2012, 2015; } \\
\text { Duchamp et } \\
\text { al. 1997; } \\
\text { Villarroya, } \\
\text { Gavalda- } \\
\text { Navarro, et } \\
\text { al. 2017) }\end{array}$ \\
\hline IGFBP-2 & Protein & $\begin{array}{l}\text { Beige } \\
\text { adipocytes }\end{array}$ & - & $\begin{array}{l}\text { Enhances the } \\
\text { differentiation of } \\
\text { osteoclasts and } \\
\text { increases bone } \\
\text { density }\end{array}$ & $\begin{array}{l}\text { (Ahmad et al. } \\
2021 ; \\
\text { Rahman et } \\
\text { al. 2013; } \\
\text { DeMambro et } \\
\text { al. 2012; } \\
\text { Kawai et al. } \\
\text { 2011) }\end{array}$ \\
\hline METRNL & Cytokine & Beige & Cold exposure & Promotes & (Ahmad et al. \\
\hline
\end{tabular}


Molecular Pharmacology Fast Forward. Published on December 21, 2021 as DOI: 10.1124/molpharm.121.000328

This article has not been copyedited and formatted. The final version may differ from this version.

\section{Heartwarming Effect of BAT}

\begin{tabular}{|c|c|c|c|c|c|}
\hline & & $\begin{array}{l}\text { adipocytes, } \\
\text { mucosal } \\
\text { tissues, skin }\end{array}$ & & $\begin{array}{l}\text { activation of } \\
\text { eosinophils, } \\
\text { recruits } \\
\text { alternatively } \\
\text { activated M2 } \\
\text { macrophages in } \\
\text { WAT }\end{array}$ & $\begin{array}{l}\text { 2021; Rao et } \\
\text { al. 2014) }\end{array}$ \\
\hline Myostatin & Cytokine & $\begin{array}{l}\text { BAT, skeletal } \\
\text { muscle, heart }\end{array}$ & $\begin{array}{l}\text { Activation of } \\
\text { Agouti-related } \\
\text { peptide neurons } \\
\text { (by an energy } \\
\text { deficit) } \\
\text { promotes the } \\
\text { expression of } \\
\text { GFP8 in BAT } \\
\text { which activates } \\
\text { myostatin }\end{array}$ & $\begin{array}{l}\text { Impairs skeletal } \\
\text { muscle function, } \\
\text { insulin stimulated } \\
\text { glucose uptake, } \\
\text { and brown } \\
\text { adipocyte } \\
\text { differentiation }\end{array}$ & $\begin{array}{l}\text { (Ahmad et al. } \\
\text { 2021; Kong } \\
\text { et al. 2018; } \\
\text { Steculorum } \\
\text { et al. 2016; } \\
\text { Fournier et } \\
\text { al. 2012; Kim } \\
\text { et al. 2012; } \\
\text { Lee, Lee, } \\
\text { and Oh } \\
\text { 2019) }\end{array}$ \\
\hline $\begin{array}{l}\text { Neuregulin } 4 \\
\text { (NRG-4) }\end{array}$ & Protein & BAT, liver & Cold exposure & $\begin{array}{l}\text { Enhances WAT } \\
\text { beiging, represses } \\
\text { hepatic } \\
\text { lipogenesis, } \\
\text { protects against } \\
\text { obesity, insulin } \\
\text { resistance, and } \\
\text { hepatic steatosis }\end{array}$ & $\begin{array}{l}\text { (Ahmad et al. } \\
\text { 2021; Rosell } \\
\text { et al. 2014; } \\
\text { Wang et al. } \\
\text { 2014; } \\
\text { Christian } \\
\text { 2015; } \\
\text { Villarroya, } \\
\text { Gavalda- } \\
\text { Navarro, et } \\
\text { al. 2017; } \\
\text { Chen et al. } \\
\text { 2017) }\end{array}$ \\
\hline NGF & Protein & BAT & Cold exposure & $\begin{array}{l}\text { Increases } \\
\text { sympathetic } \\
\text { innervation and } \\
\text { promotes neurite } \\
\text { outgrowth }\end{array}$ & $\begin{array}{l}\text { (Ahmad et al. } \\
2021 ; \\
\text { Nechad, } \\
\text { Ruka, and } \\
\text { Thibault } \\
\text { 1994; Zeng } \\
\text { et al. 2019) }\end{array}$ \\
\hline $\begin{array}{l}\text { Retinol binding } \\
\text { protein } 4 \\
\text { (RBP4) }\end{array}$ & Protein & $\begin{array}{l}\text { BAT, WAT, } \\
\text { liver }\end{array}$ & $\begin{array}{l}\text { Cold exposure, } \\
\text { B3-adrenergic } \\
\text { stimulation }\end{array}$ & $\begin{array}{l}\text { Involved in the } \\
\text { transport of } \\
\text { vitamin A } \\
\text { derivatives }\end{array}$ & $\begin{array}{l}\text { (Villarroya, } \\
\text { Gavalda- } \\
\text { Navarro, et } \\
\text { al. 2017) }\end{array}$ \\
\hline SLIT2-C & $\begin{array}{l}\text { Glycoprotei } \\
\mathrm{n} \\
\text { (extracellul } \\
\text { ar matrix } \\
\text { protein) }\end{array}$ & $\begin{array}{l}\text { Beige } \\
\text { adipocytes }\end{array}$ & - & $\begin{array}{l}\text { Stimulates } \\
\text { thermogenesis } \\
\text { and improves } \\
\text { glucose } \\
\text { homeostasis; } \\
\text { promotes WAT } \\
\text { beiging }\end{array}$ & $\begin{array}{l}\text { (Ahmad et al. } \\
\text { 2021; Kang } \\
\text { et al. 2017; } \\
\text { Svensson et } \\
\text { al. 2016; Lee, } \\
\text { Lee, and Oh } \\
\text { 2019) }\end{array}$ \\
\hline $\begin{array}{l}\text { Triiodothyronin } \\
\text { e (T3) }\end{array}$ & $\begin{array}{l}\text { Protein } \\
\text { hormone }\end{array}$ & BAT & $\begin{array}{l}\text { Cold exposure, } \\
\text { B3-adrenergic } \\
\text { stimulation }\end{array}$ & $\begin{array}{l}\text { Required for } \\
\text { adaptive } \\
\text { thermogenesis in }\end{array}$ & $\begin{array}{l}\text { (Ahmad et al. } \\
2021 \text {; de } \\
\text { Jesus et al. }\end{array}$ \\
\hline
\end{tabular}


Molecular Pharmacology Fast Forward. Published on December 21, 2021 as DOI: 10.1124/molpharm.121.000328

This article has not been copyedited and formatted. The final version may differ from this version.

Heartwarming Effect of BAT

\begin{tabular}{|c|c|c|c|c|c|}
\hline & & & $\begin{array}{l}\text { (stimulates } \\
\text { thyroxin } \\
\text { deiodinase type } \\
\text { II, the enzyme } \\
\text { which converts } \\
\text { thyroxin into the } \\
\text { active form of } \\
\text { Triiodothyronine } \\
\text { ) }\end{array}$ & $\begin{array}{l}\text { BAT; several } \\
\text { systemic effects } \\
\text { including control } \\
\text { of metabolism, } \\
\text { cardiac and } \\
\text { digestive } \\
\text { functions, brain } \\
\text { development and } \\
\text { bone maintenance }\end{array}$ & $\begin{array}{l}\text { 2001; Silva } \\
\text { and Larsen } \\
\text { 1985; } \\
\text { Villarroya, } \\
\text { Gavalda- } \\
\text { Navarro, et } \\
\text { al. 2017) }\end{array}$ \\
\hline 12-HEPE & Oxylipin & BAT & $\begin{array}{l}\text { Cold exposure, } \\
\beta 3 \text {-adrenergic } \\
\text { stimulation }\end{array}$ & $\begin{array}{l}\text { Promotes glucose } \\
\text { uptake into BAT } \\
\text { and skeletal } \\
\text { muscle }\end{array}$ & $\begin{array}{l}\text { (Leiria et al. } \\
\text { 2019). }\end{array}$ \\
\hline 12,13-diHOME & Oxylipin & BAT, liver & $\begin{array}{l}\text { Cold, exercise, } \\
\text { BAT Tx }\end{array}$ & $\begin{array}{l}\text { Promotes fatty } \\
\text { acid uptake into } \\
\text { BAT skeletal } \\
\text { muscle, and } \\
\text { cardiomyocytes, } \\
\text { increases CM } \\
\text { function and LV } \\
\text { hemodynamics }\end{array}$ & $\begin{array}{l}\text { (Lynes et al. } \\
\text { 2017; } \\
\text { Stanford et } \\
\text { al. 2018; } \\
\text { Pinckard et } \\
\text { al. 2021) }\end{array}$ \\
\hline
\end{tabular}




\section{Figure 1}

Greater hepatic lipid clearance

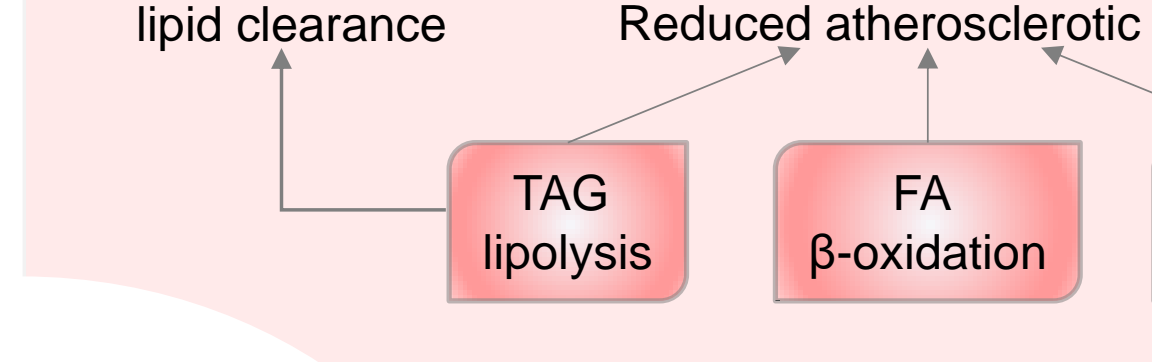

Lower circulating lipids

Reduced atherosclerotic lesion

\section{Cold}
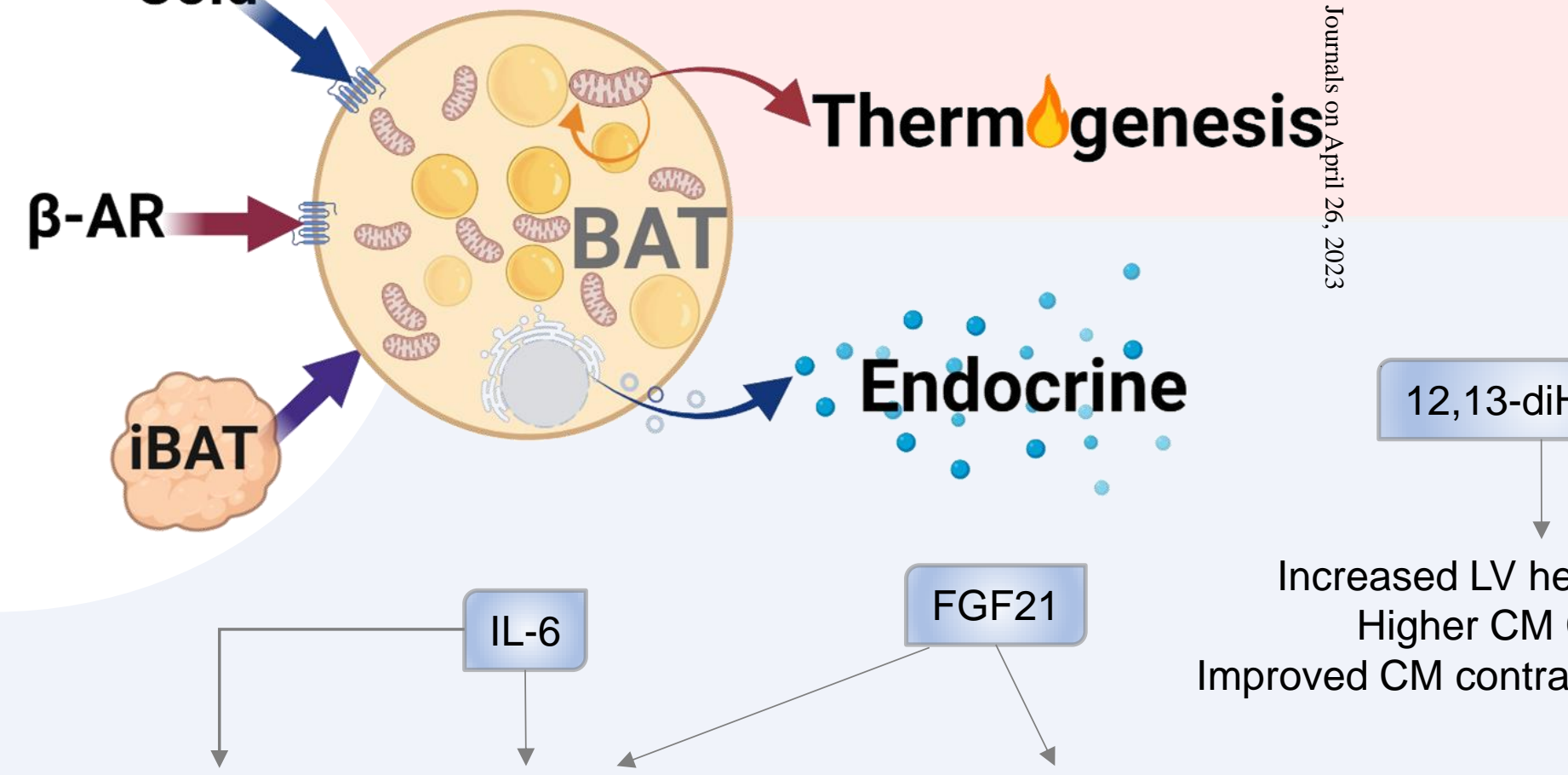

Lower weight

gain

Decreased MI

injury

$\because$ Endoocrine

FGF21

12,13-diHOME

Increased LV hemodynamics

Higher $\mathrm{CM} \mathrm{Ca}^{2+}$ flux

Improved CM contraction and kinetics

Reduced hypertension

Lower hypertrophy 